\title{
Uncovering hidden jewels: an investigation of the pictorial layers of an 18th-century Taskin harpsichord
}

\author{
Ioana Maria Cortea, Luminița Ghervase* ${ }^{*}$, Lucian Ratoiu, Monica Dinu and Roxana Rădvan
}

\begin{abstract}
The Peleș National Museum in Sinaia, Romania, includes within its collection of musical instruments a unique harpsichord of the Taskin workshop. The instrument is representative of the eighteenth century French harpsichords, finished in 1772 by Taskin Pascal, a master instrument-maker of his time. This paper presents the results of a comprehensive diagnostic investigation carried out on the exterior decoration of the harpsichord, by means of multiple non-invasive and micro-invasive analytical techniques: multispectral imaging, X-ray fluorescence (XRF) spectroscopy, laser-induced breakdown spectroscopy (LIBS), Fourier transform infrared spectroscopy (FTIR), and optical microscopy $(\mathrm{OM})$. Imaging investigation highlighted various past interventions and restorations - fillings, consolidation and chromatic reintegration of the paint layer, as well as some interesting details related to the preparatory layer and on the painting technique. Results of the elemental analysis indicated that a rich color palette was used for the luxurious decorations: vermilion for most of the red areas, lead white, a copper-based pigment for the blue and violet hues, along with Prussian blue, chromium oxides for the green tones and possibly emerald green, and iron oxides for the red, yellow and ochre tones. FTIR analysis highlighted the existence of two-layers ground based on the first layer of chalk and animal glue, covered by a second oil-bound layer of lead white. Metal soaps, gypsum, barium sulfate as well as an intermediate sizing layer based on shellac were also identified. Examination of samples' cross-sections revealed a rich stratigraphy, up to ten layers being highlighted for samples taken from the case sides' painting. The presence of two gold foils on the gilded areas, one at the top and the other within the intermediate layers, provides clear evidence of later interventions. The corroborated results offer valuable physico-chemical insights on the complex history of this prestigious harpsichord with remarkable aesthetic and historical value, as well as key information for its most suitable restoration approach.
\end{abstract}

Keywords: Harpsichord, Pigments, Multispectral imaging, XRF, LIBS, FTIR

\section{Introduction}

The Peleș National Museum in Sinaia (Romania) includes within its collection of musical instruments a remarkable French harpsichord (Fig. 1) after Pascal Taskin (17231793), a master instrument-maker of his time. Taskin worked in the Blanchet workshop in Paris and inherited it in 1766, after his marriage to the widow of François

*Correspondence: ghervase@inoe.ro

National Institute for Research and Development in Optoelectronics INOE 2000, 409 Atomiștilor St., Ilfov County, Măgurele, Romania
Étienne Blanchet II. Taskin also succeeded Blanchet as facteur des clavessins $d u$ Roi (royal-instrument maker), in 1774.

The soundboard of the harpsichord is dated 1621 (Fig. 1d). It is decorated with floral motifs, and fruits, in the manner of Ruckers' instruments and bears the specific Andreas' rose depicting an angel playing the harp with the initials of the builder on the sides, surrounded by a wreath of flowers. However, the instrument appears to be a false, being listed in the extensive work of O'Brien [1] under unauthentic Ruckers instruments. Most probably, the instrument was made to resemble
Springer Open

(c) The Author(s) 2020. This article is licensed under a Creative Commons Attribution 4.0 International License, which permits use, sharing, adaptation, distribution and reproduction in any medium or format, as long as you give appropriate credit to the original author(s) and the source, provide a link to the Creative Commons licence, and indicate if changes were made. The images or other third party material in this article are included in the article's Creative Commons licence, unless indicated otherwise in a credit line to the material. If material is not included in the article's Creative Commons licence and your intended use is not permitted by statutory regulation or exceeds the permitted use, you will need to obtain permission directly from the copyright holder. To view a copy of this licence, visit http://creativecommons.org/licenses/by/4.0/. The Creative Commons Public Domain Dedication waiver (http://creativecommons.org/publicdomain/zero/1.0/) applies to the data made available in this article, unless otherwise stated in a credit line to the data. 

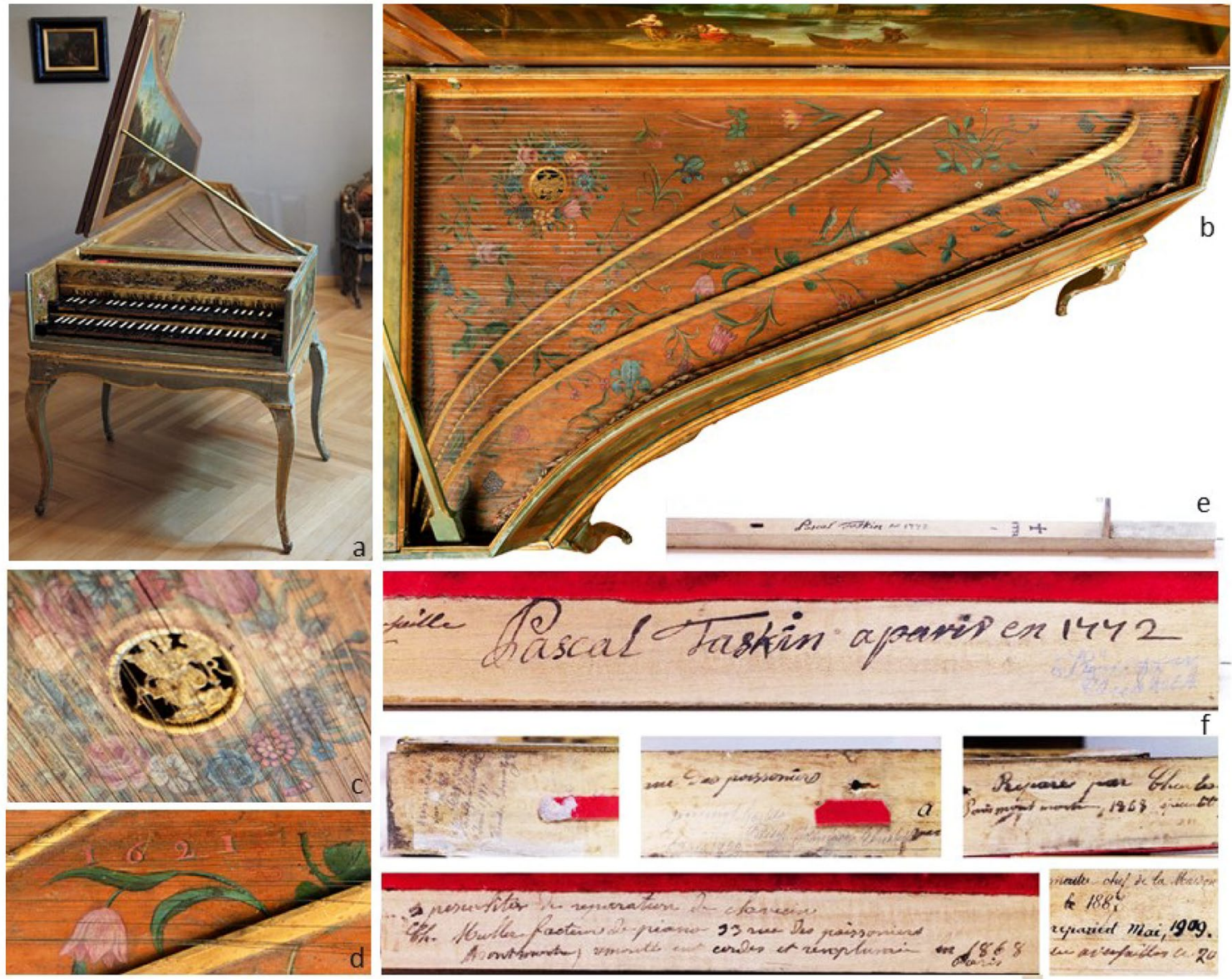

Fig. 1 Harpsichord by Pascal Taskin (Paris, 1772, collection of The Peleș National Museum): front view (a) top view of the soundboard (b) details showing an Andreas Ruckers' rose (c) and supposed year of completion (d) interior details showing Taskin's signature, location, and date as well as other inscriptions of restorers $(\mathbf{e}, \mathbf{f})$

an original Rucker's instrument, so as to increase its value. It is not, however, implausible that parts of one or more original Ruckers instruments could have been inserted into this one (as traces of a virginal bridge, tuning pins and 4' hitchpins can be seen). Original Flemish instruments were admired for their sound quality and Ruckers' harpsichords were frequently rebuilt and redecorated by French harpsichord makers, especially by the Blanchet family, the most important French harpsichord builders of the eighteenth century $[2,3]$. Original Ruckers' instruments were so sought after, that is was a common practice to counterfeit the soundboard roses, and thus pass a fake instrument for an original Ruckers $[4,5]$, therefore increasing its value. What is clear is that it is in whole or in part the work of Taskin, as his signature and the year of completion (1772) can be found both on the back of the namebatten (Fig. 1e) and on the first lower-manual keylever (Fig. 1f).
From its known history, the instrument was initially owned by the royal family of France [6], and it was bought in 1879 by Felix Bamberg (an art historian and writer) for the royal collection of paintings and art objects of Carol I, King of Romania. The historical Taskin instrument characteristic for the eighteenth century double-manual harpsichords [3], is manufactured from lime and beech wood, with ebony and bone on the keyboards [7]. The instrument has an elaborated decoration with beautiful marine scenes on the case and lid interior and floral ornamental motifs on the lid exterior, keywell and soundboard. Each part of the case is treated as a separate panel, outlined with rectangular golden bands. The five-octaves (FF, to $\mathrm{f}^{\prime \prime}$ ) instrument has $2.24 \mathrm{~m}$ length, and has undergone several restoration interventions along the time. Although some of them (in 1775 (or 1795?), $1868,1887,1909)$ can be clearly distinguished from the inscriptions on the harpsichord (see Fig. 1f), there is no history regarding what these interventions had involved. 
A specific feature of Taskin's work on the later instruments he created is the presence of the rail between the 4-foot bridge and the 8-foot bridge, which goes under the soundboard, into which the 4-foot pins run [8,9]. Overall, the harpsichord is a beautiful eighteenth century French instrument, and it represents an inestimable piece, being classified in the Thesaurus category in the national Romanian patrimony [10].

Most of the existing literature on harpsichords is focused on historical studies [2, 3], styles of the decoration $[11,12]$ or instrument's complex sound mechanism [13], with fewer studies focused on the analytical investigation of the exterior decoration in terms of color palette and technique $[5,9,14]$. Harpsichords were decorated or redecorated (ravalement of Flemish instruments) to keep them current with the furniture fashion of the epoch [15]. An analytical study of the harpsichord painted decoration can provide important information on the painting materials used on this Taskin instrument, as well as key information for its best conservation strategy.

At the moment of the investigation, the action of insects and mold had led the instrument in a precarious state, a complete restoration process being of utmost urgency. The restoration process has been structured into three main steps: the first was the expertise of the object, followed by the restoration of the musical mechanisms, the resonant parts and the resistance structure-frame, stands, and afterward by the restoration of the pictorial layers. The present study is based on the work performed in view of restoring the paintings on the harpsichord.

For an in-depth characterization of the pictorial layers, a wide array of non-invasive and micro-invasive analytical techniques have been applied. Selected analytical protocol aimed to limit as much as possible the sampling, while at the same time to obtain a large set of significant data. Multispectral imaging was used to document preparatory sketches, paint layer degradations, retouches or past conservation interventions. X-ray fluorescence (XRF) spectroscopy and Laser-induced breakdown spectroscopy (LIBS) were employed to characterize the elemental composition of the pictorial layers. Elemental analysis was performed both in situ as well as on a limited number of samples. Fourier transform infrared spectroscopy (FTIR) was used to identify both inorganic and organic materials in specific sampled areas. Optical microscopy was also used to investigate the paint layer stratigraphy of the samples.

\section{Experimental}

\section{Optical microscopy}

Optical microscopy (OM) was performed on 7 samples using a Leica M205FA fluorescence stereomicroscope. Samples have been taken from areas where the paint layer was detached, as shown in Fig. 2 (with Additional file 1), so as to limit the invasiveness on the object. No pre-treatment has been performed on the samples, they have been analyzed as extracted from the paint layer, using only custom-made holders for the positioning of the samples on the microscopy plate. Photomicrographs were acquired with the $0.63 \times$ PlanApo objective, at different magnifications, ranging from $50.4 \times$ to $101 \times$. The acquired images are shown in Table 1, along with a short description (sampling area, type, size).

\section{Multispectral imaging}

Imagistic characterization was achieved via multispectral imaging, between 400 and $1150 \mathrm{~nm}$. MSI was performed with the ARTIST multispectral digital camera, equipped with a CCD progressive scan image sensor (spectral range $365-1100 \mathrm{~nm}$ ), manufactured by Art-Innovation with a Schneider-Kreuznach Xenoplan 1.4/35 C-mount lens. As a UV radiation source, a gas discharge lamp, with a maximum peak at $365 \mathrm{~nm}$, from UVP Analytik Jena was used. For Visible and NIR imaging the lighting was ensured by two, low-intensity halogen lamps, provided also by the multispectral camera manufacturer. The recorded imaging modes were: UV fluorescence, UV reflectance, Visible Black and White, Visible color, Nearinfrared 1 and 2, False color-infrared 1 and 2. The infrared bands are used for documenting the successive paint layers and determining the possible sketches, markings, retouches, while the UV is used for the qualitative assessment of the varnish layer, identifying possible unseen deteriorations/lacunas/discontinuities [16, 17]; the VIS band is used for the digital recording of images in visible domain and the relative positioning of information from successive layers [16-19]. MSI was used on all painted areas of the harpsichord.

\section{X-ray fluorescence (XRF)}

XRF was employed using a portable, hand-held energydispersive instrument from Brucker Elemental. The TRACER III-SD equipment has a Rh-anode X-ray tube and Si-PIN detector with a typical resolution of $190 \mathrm{eV}$ at $10,000 \mathrm{cps}$. The spot size of the instrument is $3 \times 4 \mathrm{~mm}$. For a more accurate positioning on the investigated surface, the equipment has an integrated camera. For this study, the working parameters were set at $10.60 \mu \mathrm{A}$ current intensity, $40 \mathrm{kV}$ tube voltage, no filtering, air atmosphere, $60 \mathrm{~s}$ analysis time. The energy response was recorded between 0 and $40 \mathrm{keV}$, with the S1 PXRF software (Bruker AXS Handheld Inc.). Elemental identification was possible by using the standard Bayesian deconvolution with the ARTAX software (version 7.4.0.0, Bruker AXS MA) and data post-processing was performed with Microsoft Office Excel 2016. At the start 


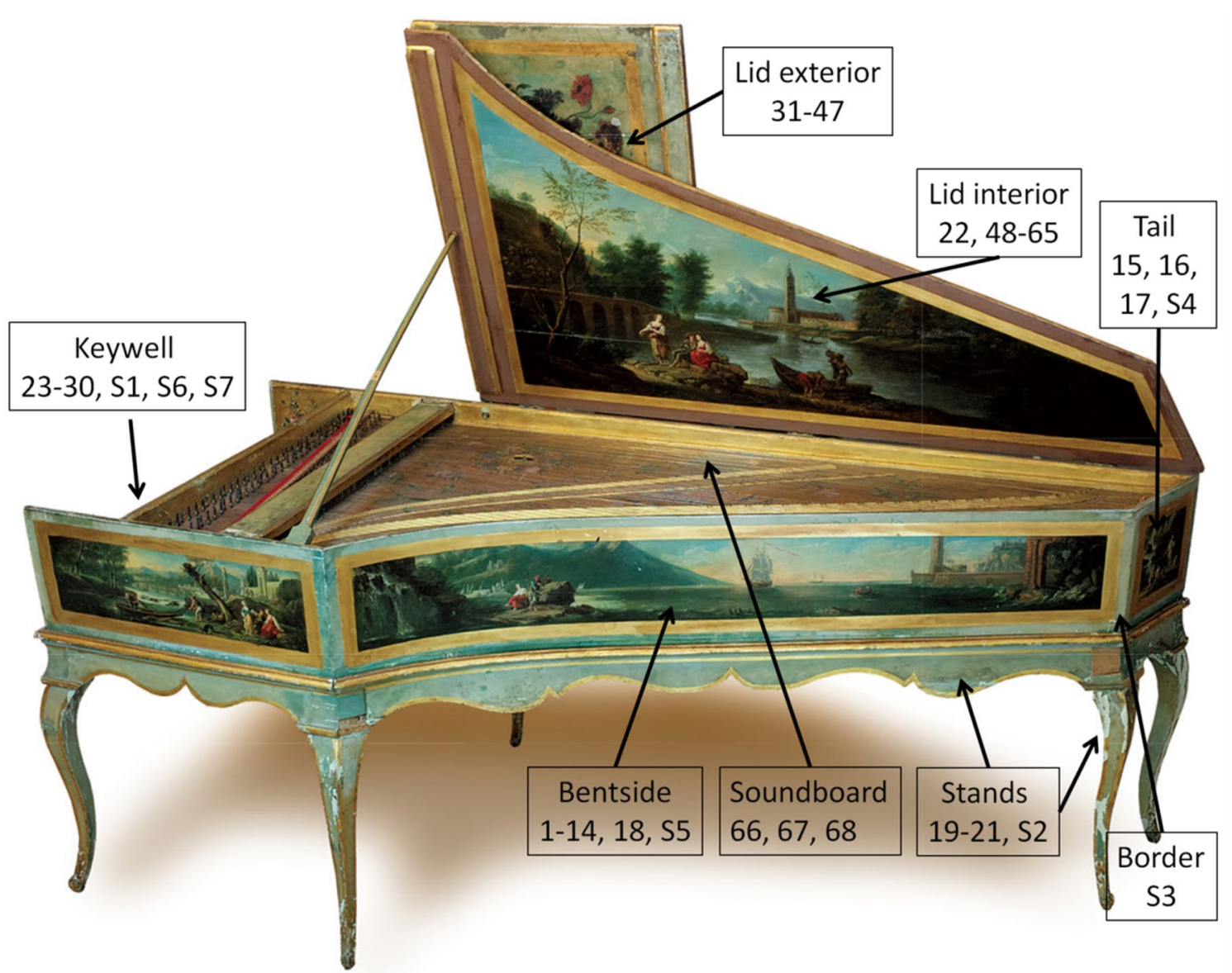

Fig. 2 Main XRF analysis (1-68) and sampling (S1-S7) areas

of each measurement session, instrument stability was checked using a stainless-steel alloy (Duplex 2205). XRF spectroscopy was applied on multiple sides of the harpsichord, as illustrated in Fig. 2 (with Additional file 1), a total of 68 spectra having been recorded. The samples collected from the instrument have also been analyzed by XRF, both on the pictorial layer and on the back of the samples, so as to better compare with the FTIR and LIBS results.

\section{Laser-induced breakdown spectroscopy (LIBS)}

The LIBS spectra of three of the samples (S1, S3, S6on the face and the verso of the samples) were recorded using a handheld spectrometer from SciAps that operates in Argon purge environment. The laser used for irradiation is a Q-switched Nd:YAG, emitting at $1064 \mathrm{~nm}$, an energy of $5 \mathrm{~mJ}$ and a laser spot of $50 \mu \mathrm{m}$. The system is equipped with three spectrometers that provide a spectral range from $190 \mathrm{~nm}$ out to $950 \mathrm{~nm}$. LIBS was used for identifying chemical elements and stratigraphy. The chemical lines within the spectra were identified using the NIST database.

\section{Fourier transform infrared spectroscopy (FTIR)}

Fourier-transform infrared spectroscopy was applied on samples (face, verso) using a Perkin Elmer Spectrum Two FTIR spectrometer equipped with a PIKE GladiATR accessory. Spectra were acquired in the 4000-370 $\mathrm{cm}^{-1}$ spectral region, at a resolution of $4 \mathrm{~cm}^{-1}$, with an average of 32 scans. Spectra are presented in transmission (\%T), with baseline correction. Data processing was done with Essential FTIR Spectroscopy Software Toolbox.

\section{Results and discussions \\ Optical microscopy}

Optical microscopy (OM) was performed on seven samples (S1-S7), from different locations, as illustrated in Fig. 2. Information about the samples is listed in Table 1, along with the chemical elements identified via XRF and the information obtained through FTIR technique. The images acquired for the sections of the samples revealed 
Table 1 Synthetic results of the physico-chemical analysis obtained on the investigated samples

\begin{tabular}{|c|c|c|c|c|}
\hline Sample & $\begin{array}{l}\text { Description (location, typology, } \\
\text { size) }\end{array}$ & Micro details & XRF detected elements ${ }^{a}$ & FTIR identification \\
\hline \multirow[t]{3}{*}{ S1 } & \multirow[t]{3}{*}{$\begin{array}{l}\text { Keywell, gold foil, } \\
2.60 \times 2.25 \times 0.25 \mu \mathrm{m}\end{array}$} & Painting & $\mathbf{Z n}, \mathbf{P b}, \mathrm{Fe}, \mathrm{Au}, \mathrm{Ca}, \mathrm{Cu}, \mathrm{Ba}, \mathrm{Sr}, \mathrm{Mn}, \mathrm{Cr}$ & $\begin{array}{l}\text { Lead white, shellac, Prussian blue, } \\
\text { ochre (kaolinite, quartz, iron oxides) } \\
\text { gypsum, barium sulfate, metal } \\
\text { soaps, oil/protein binder }\end{array}$ \\
\hline & & & $\mathbf{P b}, \mathrm{Fe}, \mathrm{Bi}, \mathrm{Cu}, \mathrm{Mn}, \mathrm{Ti}, \mathrm{Zn}, \mathrm{Ca}, \mathrm{Sr}$ & $\begin{array}{l}\text { Lead white, lipids, proteinaceous } \\
\text { materials (?) }\end{array}$ \\
\hline & & Ground & & \\
\hline \multirow[t]{2}{*}{ S2 } & \multirow[t]{2}{*}{ Stands, green, $1.70 \times 1.85 \times 0.20 \mu \mathrm{m}$} & \multirow{2}{*}{ Painting } & $\begin{array}{l}\mathrm{Pb}, \mathrm{Fe}, \mathrm{Ca}, \mathrm{Cu}, \mathrm{Co}, \mathrm{Ti} / \mathrm{Ba}, \mathrm{Mn}, \mathrm{Zn}, \mathrm{Bi} \\
\quad \mathrm{Sr}, \mathrm{Cr}, \mathrm{Si}, \mathrm{Al}\end{array}$ & $\begin{array}{l}\text { Lead white, ochre (kaolinite, quartz, } \\
\text { iron oxides), gypsum, oil/protein } \\
\text { binder }\end{array}$ \\
\hline & & & $\begin{array}{l}\mathrm{Ca}, \mathrm{Pb}, \mathrm{Fe}, \mathrm{Cu}, \mathrm{Mn}, \mathrm{Zn}, \mathrm{Ti}, \mathrm{Co}, \mathrm{Sr}, \mathrm{Hg} \\
\quad \mathrm{Cr}, \mathrm{Si}, \mathrm{Bi}\end{array}$ & $\begin{array}{l}\text { Lead white, gypsum, chalk, umber } \\
\text { (magnesium oxide, iron oxide, kao- } \\
\text { linite, quartz), lipids, proteinaceous } \\
\text { materials }\end{array}$ \\
\hline \multirow[t]{2}{*}{ S3 } & \multirow[t]{2}{*}{ Border, green, $3.30 \times 2.56 \times 0.27 \mu \mathrm{m}$} & & $\mathbf{Z n}, \mathrm{Pb}, \mathrm{Fe}, \mathrm{Sr}, \mathrm{Ba}, \mathrm{Cu}, \mathrm{Ca}$ & $\begin{array}{l}\text { Lead white, Prussian blue, ochre } \\
\text { (kaolinite, quartz, iron oxides), metal } \\
\text { soaps, oil/protein binder }\end{array}$ \\
\hline & & & $\mathrm{Pb}, \mathrm{Fe}, \mathrm{Bi}, \mathrm{Cu}, \mathrm{Zn}, \mathrm{Ba}, \mathrm{Ca}, \mathrm{Hg}$ & $\begin{array}{l}\text { Lead white, lipids, proteinaceous } \\
\text { materials (?) }\end{array}$ \\
\hline
\end{tabular}


Table 1 (continued)

\begin{tabular}{|c|c|c|c|c|}
\hline Sample & $\begin{array}{l}\text { Description (location, typology, } \\
\text { size) }\end{array}$ & Micro details & XRF detected elements ${ }^{a}$ & FTIR identification \\
\hline \multirow[t]{2}{*}{$\overline{S 4}$} & Tail, green, $1.33 \times 1.53 \times 0.25 \mu \mathrm{m}$ & Painting & $\mathbf{P b}, \mathbf{Z n}, \mathrm{Cu}, \mathrm{Fe}, \mathrm{Ba}, \mathrm{Ca}$ & $\begin{array}{l}\text { Lead white, gypsum, Prussian blue, } \\
\text { ochre (kaolinite, quartz, iron oxides), } \\
\text { metal soaps, oil/protein binder }\end{array}$ \\
\hline & & & $\mathrm{Ca}, \mathrm{Pb}, \mathrm{Fe}, \mathrm{Cu}, \mathrm{Zn}, \mathrm{Ti}$ & Chalk, proteinaceous materials \\
\hline \multirow[t]{2}{*}{ S5 } & $\begin{array}{l}\text { Bentside, blue-green, } \\
1.27 \times 1.20 \times 0.56 \mu \mathrm{m}\end{array}$ & Painting & $\mathbf{Z n}, \mathrm{Pb}, \mathrm{Fe}, \mathrm{Ca}, \mathrm{Cu}, \mathrm{Ba}, \mathrm{Mn}, \mathrm{Sr}, \mathrm{Bi}, \mathrm{Hg}$ & $\begin{array}{l}\text { Lead white, shellac, Prussian blue, } \\
\text { emerald green (?), ochre (kaolinite, } \\
\text { quartz, iron oxides), barium sulfate, } \\
\text { metal soaps, oil/protein binder }\end{array}$ \\
\hline & & & $\mathrm{Pb}, \mathrm{Ca}, \mathrm{Zn}, \mathrm{Fe}, \mathrm{Cu}, \mathrm{Ba}, \mathrm{Si}, \mathrm{S}$ & $\begin{array}{l}\text { Chalk, lead white, lipids, proteinaceous } \\
\text { materials }\end{array}$ \\
\hline \multirow[t]{2}{*}{ S6 } & $\begin{array}{l}\text { Keywell, gold foil, } \\
2.87 \times 1.40 \times 0.56 \mu \mathrm{m}\end{array}$ & & $\mathrm{Pb}, \mathrm{Cu}, \mathrm{Ca}, \mathrm{Au}, \mathrm{Fe}, \mathrm{Zn}, \mathrm{Mn}, \mathrm{Ti}$ & $\begin{array}{l}\text { Lead white, shellac, ochre (kaolinite, } \\
\text { quartz, iron oxides), metal soaps, oil/ } \\
\text { protein binder }\end{array}$ \\
\hline & & & $\mathrm{Ca}, \mathrm{Pb}, \mathrm{Cu}, \mathrm{Fe}, \mathrm{Ti}, \mathrm{Sr}, \mathrm{Mn}, \mathrm{Au}$ & $\begin{array}{l}\text { Chalk, lead white, lipids, proteinaceous } \\
\text { materials }\end{array}$ \\
\hline \multirow[t]{2}{*}{ S7 } & Keywell, red, $1.02 \times 0.66 \times 0.36 \mu \mathrm{m}$ & & $\mathrm{Ca}, \mathrm{Pb}, \mathrm{Cu}, \mathrm{Fe}, \mathrm{Zn}, \mathrm{Ti}, \mathrm{Hg}, \mathrm{Mn}, \mathrm{Cr}, \mathrm{Sr}$ & $\begin{array}{l}\text { Lead white, red lead (?), shellac, ochre } \\
\text { (quartz, iron oxides), barium sulfate, } \\
\text { metal soaps, oil/protein binder }\end{array}$ \\
\hline & & & $\mathrm{Ca}, \mathrm{Pb}, \mathrm{Zn}, \mathrm{Cu}, \mathrm{Fe}, \mathrm{Mn}, \mathrm{Ti}, \mathrm{Sr}, \mathrm{Cr}, \mathrm{Hg}$ & $\begin{array}{l}\text { Chalk, lead white, lipids, proteinaceous } \\
\text { materials }\end{array}$ \\
\hline
\end{tabular}

\footnotetext{
${ }^{\text {a }}$ Major elements with bold letters, minor elements with regular letters, trace elements with italic letters
} 
between 4 and 10 different layers, which infers the idea that some parts of the harpsichord have been through more interventions and restorations than others.

As can be seen from the images acquired for each sample, not only does the number of layers vary between the different parts of the instrument, but also between samples collected from the same area. For example, sample S2, taken from the stand, shows fewer layers, suggesting that might be the original color. Sample S6 and S7, taken from the keywell, both have 4 layers, but sample S1, taken from the same area, shows 8 (9?) layers. S6 and S7 show a whitish base layer, followed by a dark yellow layer, then other two layers. The difference between the number of layers between samples collected from the same area can lead to the idea that the keywell had suffered partial restoration, not an integral one, probably only on affected areas. Samples S3 and S4, taken from the border of the bentside and the tail, respectively, have 7 different layers, while the most complex stratigraphy, with 10 layers, can be seen for sample S5, taken from the bentside pictorial layer. The higher number of layers indicates that this area has suffered more interventions or restorations than other parts of the harpsichord. Another interesting aspect is that most samples, except for S2, S6 and S7, show multiple layers of similar (green) color. This may imply that throughout the changes made to the exterior of the instrument, the craftsmen working on it have tried to maintain a similar aspect. A common feature for all samples is that the ground layer is the thickest of all. A similar stratigraphy sequence can be observed, with two blue-green layers present in most samples, either on the fourth and fifth layers, or on the fifth and sixth layers.

\section{Imaging investigation}

The first observation which arose from the imagistic documentation of the harpsichord is the fact that it exhibits different styles of painting. The first one is located on the soundboard, depicting flowers, fruits and small animal figures. Another style is found on the keywell, a style which, in the opinion of Germann [12] is specific for the work of the Later Taskin Painter (most probably M. Doublet). The third style is located on the exterior of the lid and it also displays a floral motif, but very different in approach than the one mentioned previously; stylistically, this manner of painting appears much more recent, probably from the end of the nineteenth century. The fourth style refers to the narrative decorations found especially on the lateral parts of the harpsichord, but also on the interior of the lid. This is the most elaborated style, with many details in the composition, with a fine drawing and also with complex technical abilities of painting, using several layers, with a high amount of binder, a characteristic that enabled to obtain a diaphanous texture of the pictorial layer, especially visible in the natural background. Many surviving harpsichords, especially the ones that went through successive redecorations, display several painting styles. Moreover, it was a common practice to have the soundboard painting made by one atelier, while the case decoration was done frequently later, in a different workshop [12].

By analyzing the images acquired in infrared and UV fluorescence mode, several elements come to light, such as retouches, scratches, and preparatory drawings. For instance, Fig. 3 shows an example of the painting technique, at the fisherman's hat. From the comparison of the three images of the fisherman's hat (Fig. 3e-g) it can be highlighted that the red pigment corresponding to the hat of the fisherman is highly reflectant for the NIR radiation. The back of the hat contains only a small amount of the same red but mixed with a dark-brown pigment which in NIR becomes fully transparent, the radiation being able to pass through this opaque layer. This detail outlines a characteristic of the execution technique. The painter didn't cover the full shape of the hat with the red pigment and then juxtaposed another mix layer of darkbrown and red. He made this distinction of tonality since the beginning, without additional superimposing of other layers. Also highlighted in this scene, under UV fluorescence inspection, are the marks of two restoration interventions, probably realized at different periods. This is indicated by the change in the absorption level of the UV radiation-the interventions on the left side are characterized by a high UV absorption, which indicates a more recent intervention, while the other two smaller chromatic integration interventions on the right side, do not have the same type of strong absorption, and are most likely to come from an older restoration.

Figure 4 illustrates how infrared radiation can aide in identifying preparatory drawings, by using the $1100 \mathrm{~nm}$ NIR filter. The drawing was made in great detail and it can be seen that some alterations had been made at the veil of the ship, probably a pentimenti of the artist. The UV fluorescence image shows integration areas from previous restorations.

Similar situations were highlighted in various areas of the painted wood case along with further details regarding previous restorations, pertaining to different time intervals. The skillfulness of the restorers, or rather the lack of it, is obvious in certain areas, such as the one presented in Fig. 5. Retouches were highly visible in the UV fluorescence imaging. By comparing the various registered images, we can get a real size of the existing lacuna, as well as on the extent of the chromatic intervention, and it is obvious that the margin of the intervention is 

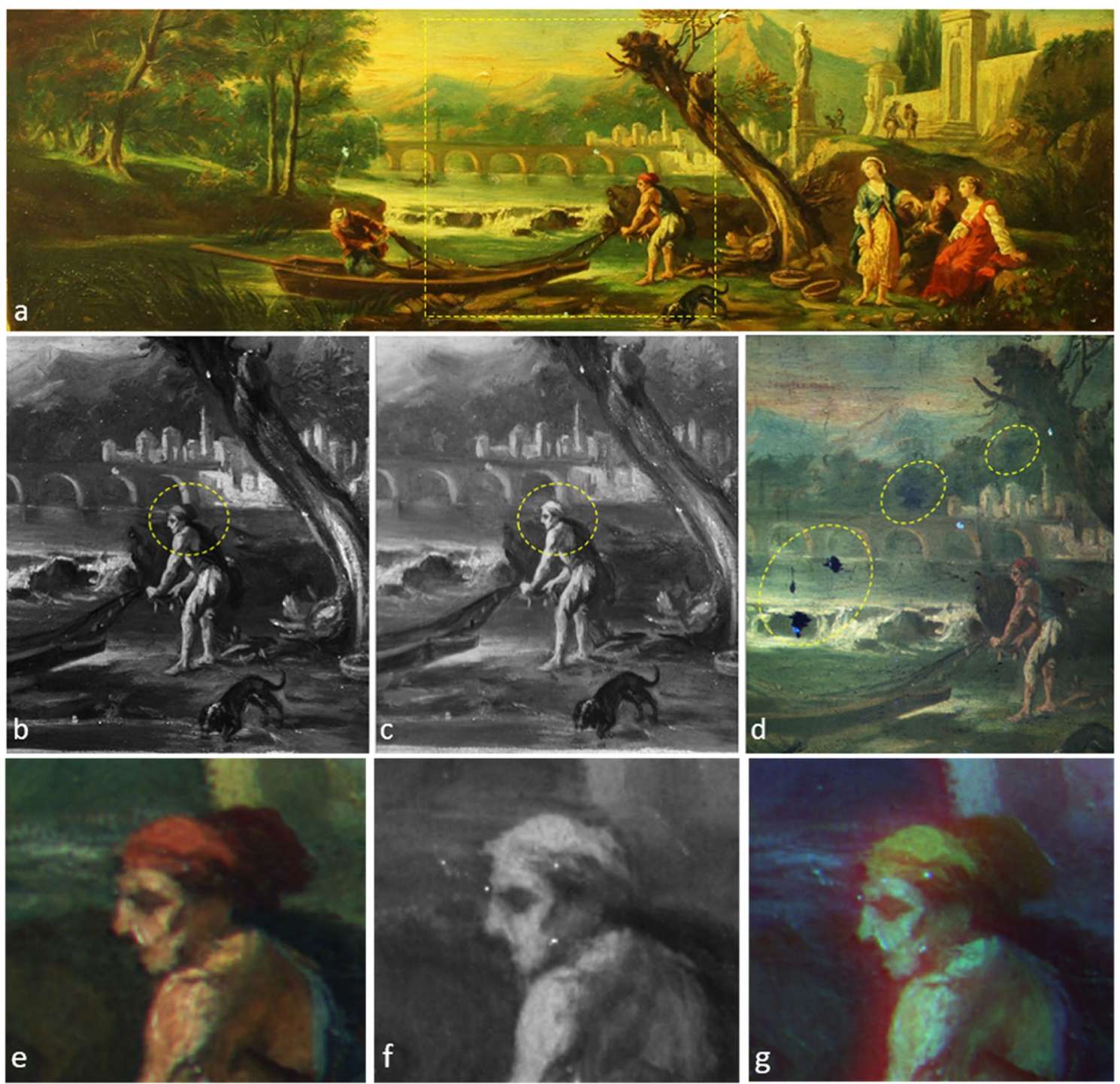

Fig. 3 Fisherman's scene: a visible color, b visible black and white, c NIR, d UV fluorescence, e visible color-detail, f NIR 2-110 nm—detail, $\mathbf{g}$ false color infrared—detail

superimposed over the original paint layer, thus indicating that they were not made by a very skillful restorer.

The corroborated analysis indicated that the object had undergone several restoration interventions along the time, some made in a rather rough manner. Such appears to be the case on the namebatten, where it can be seen that underneath the visible letters forming Andreas Ruckers' name (misspelled), there are also other letters: an upside-down „R” and "S" before and after RVKERS (as if the namebatten had been turned upside down prior to being re-written), and the markings of another letter between the $\mathrm{A}$ and $\mathrm{N}$ in ANVERPIAE (Fig. 6a, b).A similar mistaken inscription «ANDERIAS RUCKERS ANTVERPIAE $\gg$ can also be found on the namebatten of another Taskin harpsichord (now found at Museum für Kunst und Gewerbe in Hamburg) initially considered an original 1636 Andreas Ruckers instrument [4].

Another interesting detail observed during the UV examination was the orange fluorescence of some small areas located on the keywell, above the namebatten (Fig. 6e). Taking into consideration the object's age, it can come from a layer of lead white, which in our case might have been applied as a primer, mixed with linseed oil, which may reddish-yellow fluoresce instead of the usual blue-white or rose-white fluorescence, characteristic for 

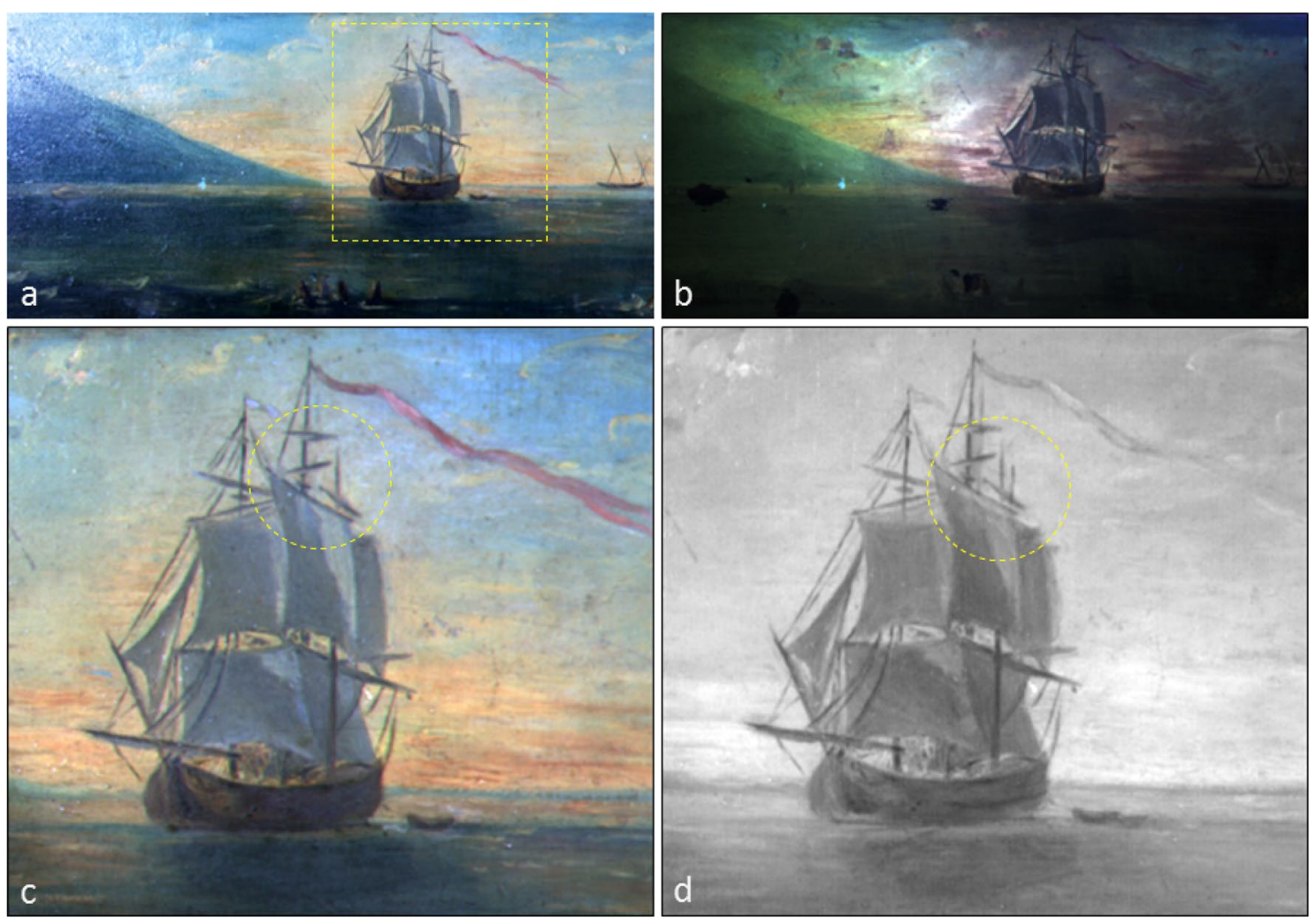

Fig. 4 Marine scene: a visible, $\mathbf{b}$ UV fluorescence, c visible — detail, $\mathbf{d}$ NIR — detail
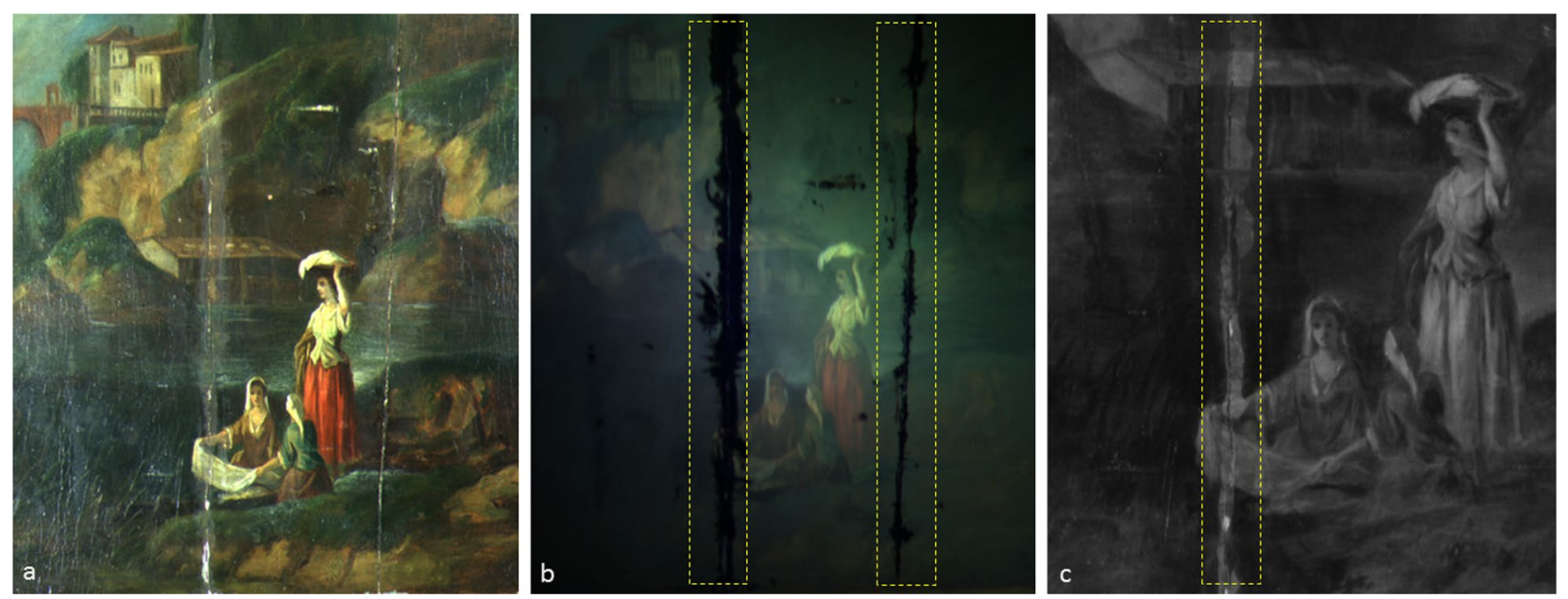

Fig. 5 Women washing clothes: a visible color, b NIR, c UV fluorescence

fresh lead white oil paint [20]. Another viable supposition may indicate the presence of an old organic layer, most probably shellac, applied as an isolating layer for the primer, before the application of the gilding [21].

Only suppositions can be made regarding the original appearance of the harpsichord. In eighteenth century
Parisian harpsichords were typically "painted one colour on the exterior and a lighter colour (often pale vermilion) was used on the interior" [11]. Gold bands were applied to divide the case and lid interiors and cabriole legs in the style of Louis XV were used, until c. 1760-1770, after which tapered, round, flutted neo-classic legs were used 


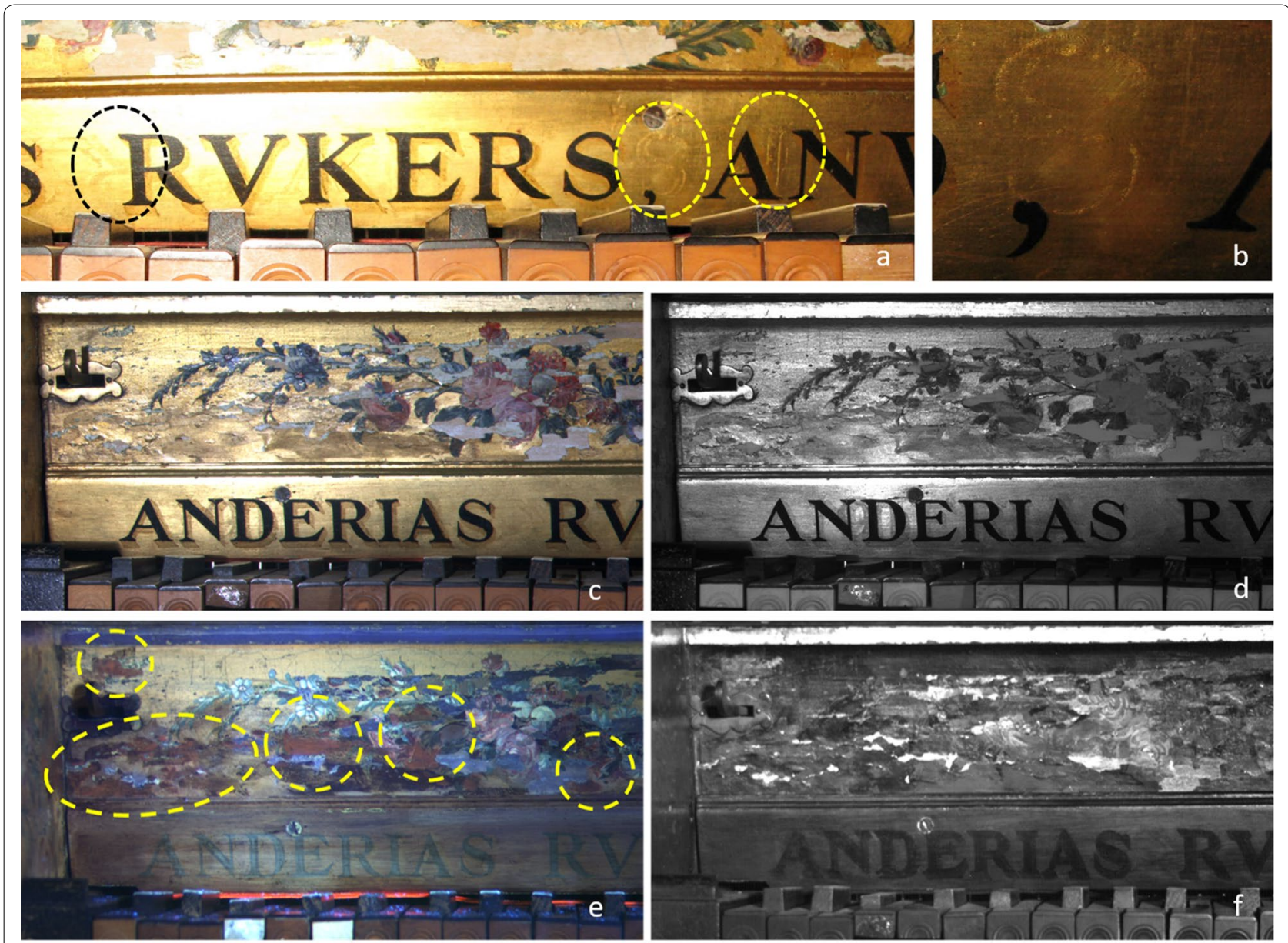

Fig. 6 Gilded area above the keyboard: a markings of older letters, $\mathbf{b}$ detail of the letter „S", c visible color, $\mathbf{d}$ visible black and white, e UV fluorescence, $\mathbf{f}$ NIR

$[1,11]$. Simple instruments had only the soundboard painted-frequently with flowers, fruits or birds, inspired from the seventeenth century Flemish harpsichord decoration, while the more elaborated instruments had also lid paintings typically displaying Italian landscapes [11]. In comparison, the case exterior of early Flemish instruments was painted rather simple, the dominant colors being bright red (vermilion) or green porphyry stone trompe-l'oeil [5]. The inside lids were frequently decorated with block printed papers and Latin mottoes [1]. Stylistically, the outer case decoration of the Taskin harpsichord within the Peleș National Museum resembles extremely well with the one found on the 1636 Andreas Ruckers harpsichord (re-modeled in 1763 by Henri Hemsch in Paris), from the Cobbe Collection. The narrative scenes which decorate the harpsichord exhibit a powerful inspiration from the Romanticism movement, picturesque landscapes with antique ruins. The technical quality of execution reflects a well-preserved tradition of painting, in most parts of the instrument, except the exterior decoration of the top wooden lid. This painting with floral motifs displays a different approach in execution, a more impasto technique and decorative finish.

\section{Painting materials}

The XRF analysis identified various chemical elements, at different intensities, some linked to the preparation layer, other to the pigments used throughout the lifetime of the harpsichord. Table 2 summarizes the elements found via XRF, correlated with the chromatic areas, as identified visually.

The corroborated investigation into the painting materials revealed a large color palette, including shades of red, blue, yellow, green, white, black and gilding, which will be discussed in the following sections. 


\section{Ground layers}

Calcium showed the highest levels on the lacunas and keywell, but also in the areas where the superior layer was cracked or in the integration areas. Furthermore, as can be seen in the XRF results (Table 2), $\mathrm{Pb}$ is predominant in all analyzed areas, except for the lacunas; higher $\mathrm{Pb}$ levels were found also in the retouching/integration areas on the exterior lid, areas which also have the highest $\mathrm{Si}$ content $(31,39,46)$. The ratio between the $L \alpha$ and $\mathrm{L} \beta$ lines of lead suggests the fact that there is a lead-based preparation layer. Higher values of the ratio have been determined also for areas 31, 39 and 46, in integration zones, possibly because X-rays reach, through the cracks, to the preparation layer. Therefore, it is possible that a calcium ground was used, on top of which the lead-rich preparation layer had been superposed. LIBS stratigraphy performed on the back of sample S3 (Fig. 7) confirms this hypothesis, as $\mathrm{Pb}$ and $\mathrm{Ca}$ appear as major elements in the first six pulses. Calcium-based grounds were very common for the eighteenth century, however, calcium carbonate $\left(\mathrm{CaCO}_{3}\right)$ was preferred in the Northern European countries, while in Eastern Europe calcium sulfate $\left(\mathrm{CaSO}_{4}\right)$ was preferred [9].

As for the Si content, the higher levels detected in areas which had lacunas of the superior layer (such as areas 31, 39, and 46), thus exposing underneath layers, correlate with the FTIR analysis of the samples, which indicated Si-rich minerals, such as kaolinite and/or quartz, in the layers beneath the surface one. Thus, the recorded $\mathrm{Si}$ is not related to the surface layer(s), but rather to the underneath layers rich in Si minerals.

Registered FTIR data confirms the use of a double ground layer based on a first layer of chalk and protein (Fig. 8a), followed by a second layer based on a lead white ground with oil (Fig. 8b). Chalk, one of the most frequently mentioned mineral fillers for ground layers in North West European recipes [22, 23] was identified by the strong peaks observed around $\sim 1400,872$ and $712 \mathrm{~cm}^{-1}$ (C-O stretching of carbonate) and the two weak peaks centered at $2513 \mathrm{~cm}^{-1}$ and $1795 \mathrm{~cm}^{-1}$ which are combinations and overtone bands $[23,24]$. The $\mathrm{C}-\mathrm{H}$ stretching absorptions around $2900 \mathrm{~cm}^{-1}$ clearly tell that there is an organic binder. Proteinaceous compounds could be inferred based on the Amide I and Amide II absorptions observed around $1646 \mathrm{~cm}^{-1}(\mathrm{C}=\mathrm{O}$ stretching) and $1540 \mathrm{~cm}^{-1}(\mathrm{~N}-\mathrm{H}$ bending and $\mathrm{C}-\mathrm{N}$ stretching) $[25,26]$, most probably an animal glue [22]. Due to spectral interferences with the very broad and strong band of the calcium carbonate anions (in chalk) [26], the Amide II band around $1539 \mathrm{~cm}^{-1}$ could be observed only in some of the registered spectra.

On top of the white chalk background, lead white was identified based on the strong carbonate stretching vibrations centered at 1393, 1045, 764 and $678 \mathrm{~cm}^{-1}$ [23]. The weak band around $3530 \mathrm{~cm}^{-1}$ (OH stretch), characteristic for hydrocerrusite [27], indicates that a mixture of cerussite $\left(\mathrm{PbCO}_{3}\right)$ and hydrocerussite $\left(2 \mathrm{PbCO}_{3} \mathrm{~Pb}(\mathrm{OH})_{2}\right)$ was used [28]. The presence and ratio of lead salts can vary depending on the raw materials, processing methods, and used recipes $[23,28]$. As indicated by the registered FTIR data, characteristic peaks for lipids were observed on this second ground layer around 2920, $2850 \mathrm{~cm}^{-1}$ (C-H stretching), $1730 \mathrm{~cm}^{-1}$ (carbonyl band) and $1712 \mathrm{~cm}^{-1}$ (carboxylic group and/or free carboxylates) [25, 29]. Weak bands frequently appearing as shoulder bands, were also registered within the fingerprint region around $1240 \mathrm{~cm}^{-1}(\mathrm{C}-\mathrm{C}-\mathrm{O}$ stretching), $1165 \mathrm{~cm}^{-1}$ (C-O stretching) and $1100 \mathrm{~cm}^{-1}\left(\mathrm{O}-\mathrm{CH}_{2}-\mathrm{C}\right.$ stretching), characteristic for oil paint systems [26].

Gypsum, another filler commonly used for preparatory layers, was also found in some of the analyzed samples (S1, S2, S4). Analysis of the intensity of IR characteristic absorptions bands $(3525,1620,1110,1008,667$, $596 \mathrm{~cm}^{-1}$ ) indicates the presence of gypsum in the upper layers, most probably associated with later intervention. Similar results were also obtained on another eighteenth century Taskin harpsichord [9], where gypsum was found on the fifth level of intervention. For this same samples (showing a gypsum rich content) strong peaks ascribed to lead white as well as a sharp peaks around $657 \mathrm{~cm}^{-1}$ ascribed to $\mathrm{Mn}-\mathrm{O}$ stretching vibrations [30] were observed. This last band is also Raman active, the peak at $\sim 650 \mathrm{~cm}^{-1}$ being frequently assigned to manganosite, with the band at $657 \mathrm{~cm}^{-1}$ ascribed to hausmannite impurities [31, 32]. As suggested by the registered FTIR data, most probably a manganese-containing earth, such as umber, was added. This hypothesis seems to be confirmed, XRF analysis highlighting a rich manganese content within this same samples (see Table 1). Existing recipes from the seventeenth centuries such as the ones from De Mayerne manuscript, indicate that manganeserich earths can function as siccative [22]. Another possibility for the use of this manganese containing earths could be related to ground pigmentation. Existing literature mentions that lead white was commonly adulterated with other pigments to create desired base tones [33]. Due to the superimposed paint layers it is not possible though to clearly identify the exact location of the manganese oxides within the stratigraphy.

\section{White pigments}

High $\mathrm{Pb}$ values were identified for the white areas, also, which would infer the use of lead white, typically lead carbonate hydroxide, $2 \mathrm{PbCO}_{3} \cdot \mathrm{Pb}(\mathrm{OH})_{2}$, as a pigment, one of the most used pigments in Europe since ancient times [33]. White lead, as well as lead carboxylates, could 
Table 2 Overview of the analysis areas and XRF-identified elements

\begin{tabular}{|c|c|c|c|}
\hline Area & ID & Chromatic area & Identified elements $^{\mathrm{a}}$ \\
\hline \multirow[t]{18}{*}{ Outer case } & 1 & Golden & $\mathbf{P b}, \mathbf{A u}, \mathbf{Z n}, \mathrm{Ba}, \mathrm{Fe}, \mathrm{Sr}, \mathrm{Ca}, \mathrm{Cu}, \mathrm{Bi}, \mathrm{Cr}, \mathrm{Ag}$ \\
\hline & 2 & White & $\mathbf{P b}, \mathbf{F e}, \mathrm{Ca}, \mathrm{Bi}, \mathrm{Zn}, \mathrm{Sr}, \mathrm{Ba}, \mathrm{Cu}, \mathrm{Mn}$ \\
\hline & 3 & Red-lacuna & $\mathbf{P b}, \mathbf{H g}, \mathrm{Fe}, \mathrm{Ca}, \mathrm{Zn}, \mathrm{Sr}, \mathrm{Cr}, \mathrm{Ba}, \mathrm{Bi}, \mathrm{Cu}, \mathrm{Mn}, \mathrm{Zr}$ \\
\hline & 4 & Red & $\mathbf{P b}, \mathbf{H g}, \mathbf{F e}, \mathrm{Ca}, \mathrm{S}, \mathrm{Sr}, \mathrm{Zn}, \mathrm{Ba}, \mathrm{Bi}, \mathrm{Cu}, \mathrm{Al}, \mathrm{Cr}, \mathrm{Zr}$ \\
\hline & 5 & White & $\mathbf{P b}, \mathbf{F e}, \mathrm{Bi}, \mathrm{Sr}, \mathrm{Zn}, \mathrm{Ca}, \mathrm{Ba}, \mathrm{Cu}, \mathrm{Al}$ \\
\hline & 6 & Green-border & $\mathrm{Pb}, \mathbf{Z n}, \mathrm{Ba}, \mathrm{Fe}, \mathrm{Bi}, \mathrm{Sr}, \mathrm{Ca}, \mathrm{Co}, \mathrm{Cu}, \mathrm{Cr}$ \\
\hline & 7 & Blue & $\mathrm{Pb}, \mathrm{Fe}, \mathrm{Bi}, \mathrm{Sr}, \mathrm{Zn}, \mathrm{Ca}, \mathrm{Ba}, \mathrm{Co}, \mathrm{Cu}$ \\
\hline & 8 & Golden-border & $\mathbf{P b}, \mathbf{A u}, \mathrm{Fe}, \mathrm{Ba}, \mathrm{Zn}, \mathrm{Sr}, \mathrm{Ca}, \mathrm{Cu}, \mathrm{Cr}, \mathrm{Bi}, \mathrm{Ag}$ \\
\hline & 9 & Golden-reddish- border & $\mathbf{P b}, \mathbf{Z n}, \mathbf{A u}, \mathbf{F e}, \mathrm{Ba}, \mathrm{Sr}, \mathrm{Ca}, \mathrm{Cu}, \mathrm{Cr}, \mathrm{Bi}, \mathrm{Mn}, \mathrm{Cl}, \mathrm{Ag}, \mathrm{K}$ \\
\hline & 10 & Dark brown-black & $\mathrm{Pb}, \mathrm{Fe}, \mathrm{Ca}, \mathrm{Bi}, \mathrm{Zn}, \mathrm{Sr}, \mathrm{Ba}, \mathrm{Mn}, \mathrm{Cu}, \mathrm{Cr}, \mathrm{K}, \mathrm{Si}$ \\
\hline & 11 & Green-border & $\mathbf{P b}, \mathbf{Z n}, \mathrm{Fe}, \mathrm{Ba}, \mathrm{Bi}, \mathrm{Sr}, \mathrm{Ca}, \mathrm{Cu}, \mathrm{Cl}, \mathrm{Mn}$ \\
\hline & 12 & Black spot on golden border & $\mathbf{P b}, \mathbf{Z n}, \mathbf{A u}, \mathrm{Fe}, \mathrm{Ba}, \mathrm{Sr}, \mathrm{Ca}, \mathrm{Cu}, \mathrm{Au}, \mathrm{Bi}, \mathrm{Cr}, \mathrm{Mn}, \mathrm{Cl}, \mathrm{Ag}, \mathrm{K}$ \\
\hline & 13 & Integration on golden border & $\mathbf{P b}, \mathbf{Z n}, \mathbf{C u}, \mathbf{C a}, \mathbf{A u}, \mathrm{Fe}, \mathrm{Ba}, \mathrm{Sr}, \mathrm{Si}, \mathrm{Cr}, \mathrm{Mn}, \mathrm{Cl}, \mathrm{K}, \mathrm{Bi}, \mathrm{Al}$ \\
\hline & 14 & White-pink & $\mathrm{Pb}, \mathrm{Fe}, \mathrm{Bi}, \mathrm{Ca}, \mathrm{Zr}, \mathrm{Ti}, \mathrm{Cu}, \mathrm{Zn}, \mathrm{Mn}, \mathrm{Cr}, \mathrm{Rb}$ \\
\hline & 15 & Golden-border-lacuna & $\mathrm{Pb}, \mathbf{A u}, \mathrm{Ba}, \mathrm{Zn}, \mathrm{Sr}, \mathrm{Fe}, \mathrm{Ca}, \mathrm{Cu}, \mathrm{Bi}, \mathrm{Cr}, \mathrm{Ag}, \mathrm{Zr}$ \\
\hline & 16 & Golden-reddish-border & $\mathbf{P b}, \mathbf{Z n}, \mathbf{A u}(\mathrm{ma}) \mathrm{Fe}, \mathrm{Ba}, \mathrm{Sr}, \mathrm{Ca}, \mathrm{Cu}, \mathrm{Cr}, \mathrm{Bi}, \mathrm{Ag}, \mathrm{Zr}, \mathrm{Rb}$ \\
\hline & 17 & White & $\mathbf{P b}, \mathbf{F e}, \mathrm{Bi}, \mathrm{Sr}, \mathrm{Ca}, \mathrm{Zn}, \mathrm{Ti}, \mathrm{Cu}, \mathrm{Mn}$ \\
\hline & 18 & Brown & $\mathrm{Pb}, \mathrm{Fe}, \mathrm{Ca}, \mathrm{Zn}, \mathrm{Sr}, \mathrm{Hg}, \mathrm{Mn}, \mathrm{Bi}, \mathrm{Ba}, \mathrm{Cu}, \mathrm{Zr}$ \\
\hline \multirow[t]{3}{*}{ Stands } & 19 & Lacuna & $\mathrm{Pb}, \mathrm{Cu}, \mathrm{Ca}, \mathrm{Zn}, \mathrm{Bi}, \mathrm{Fe}, \mathrm{Zr}, \mathrm{Ba}, \mathrm{Co}$ \\
\hline & 20 & Lacuna & $\mathbf{C a}, \mathbf{P b}, \mathrm{Fe}, \mathrm{Sr}, \mathrm{Bi}, \mathrm{Cu}, \mathrm{Mn}, \mathrm{Ti}, \mathrm{K}, \mathrm{Si}$ \\
\hline & 21 & Green & $\mathbf{Z n}, \mathbf{P b}, \mathrm{Fe}, \mathrm{Ba}, \mathrm{Sr}, \mathrm{Bi}, \mathrm{Ca}, \mathrm{Mn}, \mathrm{Cu}$ \\
\hline \multirow[t]{19}{*}{ Lid interior } & 22 & Golden-border & $\mathbf{P b}, \mathbf{C u}, \mathbf{C a}, \mathbf{F e}, \mathbf{Z n}, \mathrm{Au}, \mathrm{Ba}, \mathrm{Sr}, \mathrm{Hg}, \mathrm{Bi}, \mathrm{Cr}, \mathrm{Mn}, \mathrm{K}, \mathrm{Al}$ \\
\hline & 48 & Dark green & $\mathbf{P b}, \mathrm{Fe}, \mathrm{Bi}, \mathrm{Ca}, \mathrm{Cu}, \mathrm{Zn}, \mathrm{Ti}, \mathrm{Ba}, \mathrm{Cr}$ \\
\hline & 49 & Light green-blue & $\mathrm{Pb}, \mathrm{Fe}, \mathrm{Bi}, \mathrm{Ca}, \mathrm{Cu}, \mathrm{Zn}, \mathrm{Zr}, \mathrm{Ba}$ \\
\hline & 50 & Green & $\mathbf{P b}, \mathbf{F e}, \mathrm{Bi}, \mathrm{Zn}, \mathrm{Ca}, \mathrm{Cu}, \mathrm{Ba}, \mathrm{Zr}, \mathrm{Cr}$ \\
\hline & 51 & Dark green-brown & $\mathbf{P b}, \mathbf{F e}, \mathbf{Z n}, \mathrm{Ca}, \mathrm{Bi}, \mathrm{Cu}, \mathrm{Hg}, \mathrm{Ba}, \mathrm{Cr}, \mathrm{Zr}$ \\
\hline & 52 & Dark green & $\mathbf{P b}, \mathrm{Fe}, \mathrm{Zn}, \mathrm{Cr}, \mathrm{Ca}, \mathrm{Bi}, \mathrm{Cu}, \mathrm{Hg}, \mathrm{Zr}, \mathrm{Ti}, \mathrm{Ba}$ \\
\hline & 53 & Red & $\mathbf{P b}, \mathbf{F e}, \mathbf{H g}, \mathrm{Ca}, \mathrm{Cu}, \mathrm{Bi}, \mathrm{Mn}, \mathrm{Zr}, \mathrm{Ti}, \mathrm{Cr}$ \\
\hline & 54 & White & $\mathbf{P b}, \mathbf{F e}, \mathrm{Bi}, \mathrm{Ca}, \mathrm{Zn}, \mathrm{Cu}, \mathrm{Zr}, \mathrm{Ba}, \mathrm{Cr}, \mathrm{Ti}$ \\
\hline & 55 & Green & $\mathrm{Pb}, \mathrm{Fe}, \mathbf{Z n}, \mathrm{As}, \mathrm{Cr}, \mathrm{Cu}, \mathrm{Ca}, \mathrm{Bi}, \mathrm{Zr}, \mathrm{Ti}$ \\
\hline & 56 & Light brown & $\mathbf{P b}, \mathbf{F e}, \mathrm{Ca}, \mathrm{Bi}, \mathrm{Cu}, \mathrm{Zn}, \mathrm{Ti}, \mathrm{Ba}, \mathrm{Cr}$ \\
\hline & 57 & Blue & $\mathbf{P b}, \mathrm{Fe}, \mathrm{Bi}, \mathrm{Zn}, \mathrm{Ca}, \mathrm{Cu}, \mathrm{Ba}, \mathrm{Ti}, \mathrm{Cr}$ \\
\hline & 58 & Brown & $\mathrm{Pb}, \mathrm{Fe}, \mathrm{Bi}, \mathrm{Cu}, \mathrm{Ca}, \mathrm{Zn}, \mathrm{Ti}$ \\
\hline & 59 & White-pink & $\mathrm{Pb}, \mathrm{Fe}, \mathrm{Bi}, \mathrm{Hg}, \mathrm{Ca}, \mathrm{Zn}, \mathrm{Cu}, \mathrm{Ti}$ \\
\hline & 60 & Light blue & $\mathrm{Pb}, \mathbf{Z n}, \mathrm{Fe}, \mathrm{Bi}, \mathrm{Ca}, \mathrm{Ba}, \mathrm{Cu}, \mathrm{Cr}$ \\
\hline & 61 & Brown-border & $\mathbf{P b}, \mathbf{Z n}, \mathbf{F e}, \mathrm{Ba}, \mathrm{Sr}, \mathrm{Hg}, \mathrm{Bi}, \mathrm{Ca}, \mathrm{Cu}, \mathrm{Mn}, \mathrm{Cr}, \mathrm{Si}$ \\
\hline & 62 & Brown-border & $\mathrm{Pb}, \mathbf{Z n}, \mathrm{Fe}, \mathrm{Ba}, \mathrm{Sr}, \mathrm{Hg}, \mathrm{Bi}, \mathrm{Cu}, \mathrm{Ca}, \mathrm{Cr}$ \\
\hline & 63 & Brown-border-integration & $\mathbf{P b}, \mathbf{Z n}, \mathbf{F e}, \mathrm{Ba}, \mathrm{Sr}, \mathrm{Hg}, \mathrm{Bi}, \mathrm{Ca}, \mathrm{Cu}, \mathrm{Al}, \mathrm{Cr}$ \\
\hline & 64 & Brown-border-integration & $\mathbf{Z n}, \mathbf{P b}, \mathrm{Fe}, \mathrm{Ba}, \mathrm{Sr}, \mathrm{Hg}, \mathrm{Bi}, \mathrm{Ca}, \mathrm{Cu}, \mathrm{Cr}$ \\
\hline & 65 & Brown-border-integration & $\mathbf{Z n}, \mathbf{P b}, \mathbf{F e}, \mathrm{Ca}, \mathrm{Sr}, \mathrm{Cu}, \mathrm{Mn}, \mathrm{Ca}, \mathrm{Bi}, \mathrm{Cr}, \mathrm{Hg}, \mathrm{Ba}, \mathrm{Al}, \mathrm{Si}$ \\
\hline \multirow[t]{8}{*}{ Keywell } & 23 & Lacuna & $\mathrm{Ca}, \mathrm{Pb}, \mathrm{Cu}, \mathrm{Fe}, \mathrm{Sr}, \mathrm{Zn}, \mathrm{Ba}, \mathrm{Hg}, \mathrm{Mn}, \mathrm{Au}, \mathrm{Ti}, \mathrm{Bi}$ \\
\hline & 24 & Red & $\mathbf{Z n}, \mathbf{C a}, \mathbf{P b}, \mathbf{H g}, \mathrm{Cu}, \mathrm{Fe}, \mathrm{S}, \mathrm{Cr}, \mathrm{Ba}, \mathrm{Sr}, \mathrm{Mn}, \mathrm{Rb}, \mathrm{Bi}, \mathrm{Al}$ \\
\hline & 25 & Red-pink & $\mathrm{Pb}, \mathbf{C a}, \mathbf{Z n}, \mathrm{Cu}, \mathrm{Fe}, \mathrm{Sr}, \mathrm{Hg}, \mathrm{Ba}, \mathrm{Bi}, \mathrm{Mn}, \mathrm{Ti}$ \\
\hline & 26 & Blue & $\mathbf{P b}, \mathbf{C a}, \mathbf{C u}, \mathrm{Au}, \mathrm{Fe}, \mathrm{Bi}, \mathrm{Zr}, \mathrm{Ti}, \mathrm{Mn}, \mathrm{Ba}, \mathrm{Zn}$ \\
\hline & 27 & Blue & $\mathrm{Pb}, \mathrm{Ca}, \mathrm{Cu}, \mathrm{Au}, \mathrm{Fe}, \mathrm{Bi}, \mathrm{Zn}, \mathrm{Mn}, \mathrm{Cr}, \mathrm{Ti}$ \\
\hline & 28 & Purple & $\mathbf{P b}, \mathbf{C a}, \mathbf{C u}(\mathrm{ma}) \mathrm{Au}, \mathrm{Fe}, \mathrm{Zn}, \mathrm{Sr}, \mathrm{Bi}, \mathrm{Ba}, \mathrm{Hg}, \mathrm{Mn}, \mathrm{Al}, \mathrm{Cr}$ \\
\hline & 29 & Golden & $\mathbf{P b}, \mathbf{C u}, \mathbf{A u}, \mathrm{Ca}, \mathrm{Fe}, \mathrm{Bi}, \mathrm{Ti}$ \\
\hline & 30 & White-ground & $\mathrm{Ca}, \mathrm{Pb}, \mathrm{Cu}, \mathrm{Fe}, \mathrm{Sr}, \mathrm{Ti}, \mathrm{Mn}, \mathrm{Au}, \mathrm{Bi}$ \\
\hline
\end{tabular}


Table 2 (continued)

\begin{tabular}{|c|c|c|c|}
\hline Area & ID & Chromatic area & Identified elements $^{\mathrm{a}}$ \\
\hline \multirow[t]{17}{*}{ Lid exterior } & 31 & Green-integration & $\mathbf{P b}, \mathbf{Z n}, \mathbf{F e}, \mathrm{Bi}, \mathrm{Cr}, \mathrm{Ca}, \mathrm{Sr}, \mathrm{Ba}, \mathrm{Mn}, \mathrm{Cu}, \mathrm{Si}, \mathrm{Bi}$ \\
\hline & 32 & Golden & $\mathbf{P b}, \mathbf{Z n}, \mathbf{A u}, \mathrm{Fe}, \mathrm{Sr}, \mathrm{Ca}, \mathrm{Ba}, \mathrm{Cu}, \mathrm{Bi}, \mathrm{Cr}, \mathrm{S}, \mathrm{Mn}, \mathrm{Ag}, \mathrm{Si}$ \\
\hline & 33 & Dark green & $\mathrm{Pb}, \mathrm{Fe}, \mathrm{Zn}, \mathrm{Ca}, \mathrm{Cr}, \mathrm{Sr}, \mathrm{S}, \mathrm{Ba}, \mathrm{Cu}, \mathrm{Bi}, \mathrm{Mn}, \mathrm{K}, \mathrm{Si}$ \\
\hline & 34 & White & $\mathbf{P b}, \mathbf{Z n}, \mathrm{Fe}, \mathrm{Ca}, \mathrm{S}, \mathrm{Bi}, \mathrm{Hg}, \mathrm{Cu}, \mathrm{Ba}$ \\
\hline & 35 & Red & $\mathbf{P b}, \mathbf{F e}, \mathbf{H g}, \mathrm{Zn}, \mathrm{Ca}, \mathrm{Sr}, \mathrm{Cu}, \mathrm{Cr}, \mathrm{S}, \mathrm{Mn}, \mathrm{Bi}, \mathrm{Ba}, \mathrm{K}, \mathrm{Si}$ \\
\hline & 36 & Purple & $\mathrm{Pb}, \mathrm{Fe}, \mathrm{Ca}, \mathrm{Zn}, \mathrm{Sr}, \mathrm{Hg}, \mathrm{S}, \mathrm{Sr}, \mathrm{K}, \mathrm{Bi}, \mathrm{Cr}, \mathrm{Cu}, \mathrm{Ba}, \mathrm{Mn}, \mathrm{Bi}, \mathrm{Si}$ \\
\hline & 37 & Red & $\mathbf{P b}, \mathbf{H g}, \mathrm{Fe}, \mathrm{Ca}, \mathrm{S}, \mathrm{Zn}, \mathrm{Sr}, \mathrm{Bi}, \mathrm{Cu}, \mathrm{Ba}, \mathrm{Si}$ \\
\hline & 38 & Black & $\mathbf{P b}, \mathbf{H g}, \mathbf{C a}, \mathrm{Fe}, \mathrm{Zn}, \mathrm{Sr}, \mathrm{S}, \mathrm{Ba}, \mathrm{Bi}, \mathrm{Cu}, \mathrm{K}, \mathrm{Mn}, \mathrm{Si}, \mathrm{Cr}$ \\
\hline & 39 & Green-border-integration & $\mathbf{P b}, \mathbf{Z n}, \mathrm{Fe}, \mathrm{Cr}, \mathrm{Sr}, \mathrm{Ca}, \mathrm{Bi}, \mathrm{Ba}, \mathrm{Cu}, \mathrm{Mn}, \mathrm{Hg}, \mathrm{Si}$ \\
\hline & 40 & Green-border & $\mathrm{Pb}, \mathbf{Z n}, \mathrm{Fe}, \mathrm{Ba}, \mathrm{Sr}, \mathrm{Bi}, \mathrm{Ca}, \mathrm{S}, \mathrm{Si}, \mathrm{Cu}$ \\
\hline & 41 & White-lacuna & $\mathrm{Ca}, \mathrm{Pb}, \mathrm{Fe}, \mathrm{Zn}, \mathrm{S}, \mathrm{Cu}, \mathrm{Sr}, \mathrm{K}, \mathrm{Mn}, \mathrm{Ti}, \mathrm{Si}$ \\
\hline & 42 & Yellow-green & $\mathbf{P b}, \mathbf{F e}, \mathbf{Z n}, \mathrm{Cr}, \mathrm{Ca}, \mathrm{Sr}, \mathrm{Bi}, \mathrm{S}, \mathrm{Cu}, \mathrm{Hg}, \mathrm{Ba}, \mathrm{K}, \mathrm{Mn}, \mathrm{Si}$ \\
\hline & 43 & Purple & $\mathrm{Pb}, \mathrm{Fe}, \mathrm{Zn}, \mathrm{Ca}, \mathrm{Sr}, \mathrm{Ba}, \mathrm{S}, \mathrm{Bi}, \mathrm{K}, \mathrm{Mn}, \mathrm{Cu}, \mathrm{Si}, \mathrm{Cr}$ \\
\hline & 44 & Red & $\mathbf{P b}, \mathbf{F e}, \mathbf{H g}, \mathrm{Zn}, \mathrm{Ca}, \mathrm{Sr}, \mathrm{Ba}, \mathrm{S}, \mathrm{Bi}, \mathrm{Mn}, \mathrm{Cu}, \mathrm{K}, \mathrm{Si}, \mathrm{Cr}$ \\
\hline & 45 & White & $\mathbf{P b}, \mathbf{H g}, \mathbf{F e}, \mathrm{Zn}, \mathrm{Sr}, \mathrm{Ca}, \mathrm{Ba}, \mathrm{S}, \mathrm{Bi}, \mathrm{Cu}, \mathrm{Mn}, \mathrm{K}$ \\
\hline & 46 & Green-border-lacuna & $\mathbf{P b}, \mathbf{Z n}, \mathbf{B a}, \mathrm{Pb}, \mathrm{Sr}, \mathrm{Bi}, \mathrm{Fe}, \mathrm{Ca}, \mathrm{Cu}, \mathrm{Mn}, \mathrm{Al}, \mathrm{Si}$ \\
\hline & 47 & Yellow-white & $\mathrm{Pb}, \mathrm{Fe}, \mathrm{Ca}, \mathrm{Zn}, \mathrm{Bi}, \mathrm{Sr}, \mathrm{Hg}, \mathrm{Cu}, \mathrm{Ti}$ \\
\hline \multirow[t]{3}{*}{ Soundboard } & 66 & Red & $\mathrm{Pb}, \mathrm{Fe}, \mathrm{Ca}, \mathrm{Hg}, \mathrm{Mn}, \mathrm{Cu}, \mathrm{S}$ \\
\hline & 67 & Wood & $\mathrm{Fe}, \mathrm{Ca}, \mathrm{Mn}, \mathrm{K}, \mathrm{Cu}, \mathrm{Pb}, \mathrm{S}, \mathrm{Ti}, \mathrm{Zn}, \mathrm{Si}, \mathrm{Al}, \mathrm{Rb}$ \\
\hline & 68 & White & $\mathbf{P b}, \mathrm{Fe}, \mathrm{S}, \mathrm{Ca}, \mathrm{Hg}, \mathrm{Mn}, \mathrm{Cu}, \mathrm{Rb}, \mathrm{Ti}, \mathrm{Zr}, \mathrm{Zn}, \mathrm{Al}$ \\
\hline
\end{tabular}

${ }^{a}$ Major elements with bold letters, minor elements with regular letters, trace elements with italic letters

be observed in most of the registered FTIR spectra, as well. Lead white was very common in the 17-19th centuries, and evidence of its use for decorating Taskin harpsichords, either original ones, or ravelements of older harpsichords, such as Ruckers, were found also in other literature studies [5].

The various interventions performed throughout the lifetime of the harpsichord are evident, as the parts of the instrument do not show the presence of the same elements. For instance, barium lines are present on the keywell, but not on the interior of the lid flap and the soundboard. LIBS confirmed the presence of $\mathrm{Ba}$ on sample S1, taken from the keywell, appearing from the third pulse, as a trace element, and increasing in intensity up to the twelfth pulse, and then slightly decreasing again up to the final pulse. Barium sulfate was identified by the characteristic absorptions observed at 1064, 983, and $633 \mathrm{~cm}^{-1}$, best seen in the FTIR spectra registered on the interior paint layers. First introduced in the 19thcentury recipes, barium sulfate $\left(\mathrm{BaSO}_{4}\right)$ was the most frequently used lead white extender starting with 1815 due to its optical and chemical properties compared to chalk $[22,34,35]$. Thus, the presence of barium sulfate is an indicator of a nineteenth century intervention [5]. The stratigraphic distribution showed that $\mathrm{Ba}$ has the same behavior as $\mathrm{Sr}$, indicating that they might come from a common source. The correlation of $\mathrm{Ba}$ and $\mathrm{Sr}$ is explainable, taking into account that the two elements belong to the same group of the periodic table, and it is known that $\mathrm{Sr}$ atoms tend to substitute $\mathrm{Ba}$ in the natural mineral, barite [36].

Some white shades contain $\mathrm{Pb}$ and also $\mathrm{Zn}$, probably from a combination of lead white and zinc white. Zinc might also indicate more recent interventions, as it was found at higher levels only on the green and brown borders. The presence of zinc white could also be inferred via FTIR, based on the zinc (carboxylate) soaps identifiedsharp peak at $1547 \mathrm{~cm}^{-1}$ (zinc oleate) [37]. The strong and sharp band around $1540 \mathrm{~cm}^{-1}$, frequently observed within the registered FTIR data, can be ascribed either to crystalline zinc soaps [38], either to lead palmitates and stearates [37]. The peaks centered around $1320 \mathrm{~cm}^{-1}$ and $\sim 1600 \mathrm{~cm}^{-1}$ ( $\mathrm{C}=\mathrm{O}$ stretching bands) can be associated with both calcium and copper oxalates [39] frequently found in aged paint samples. As indicated by the FTIR 


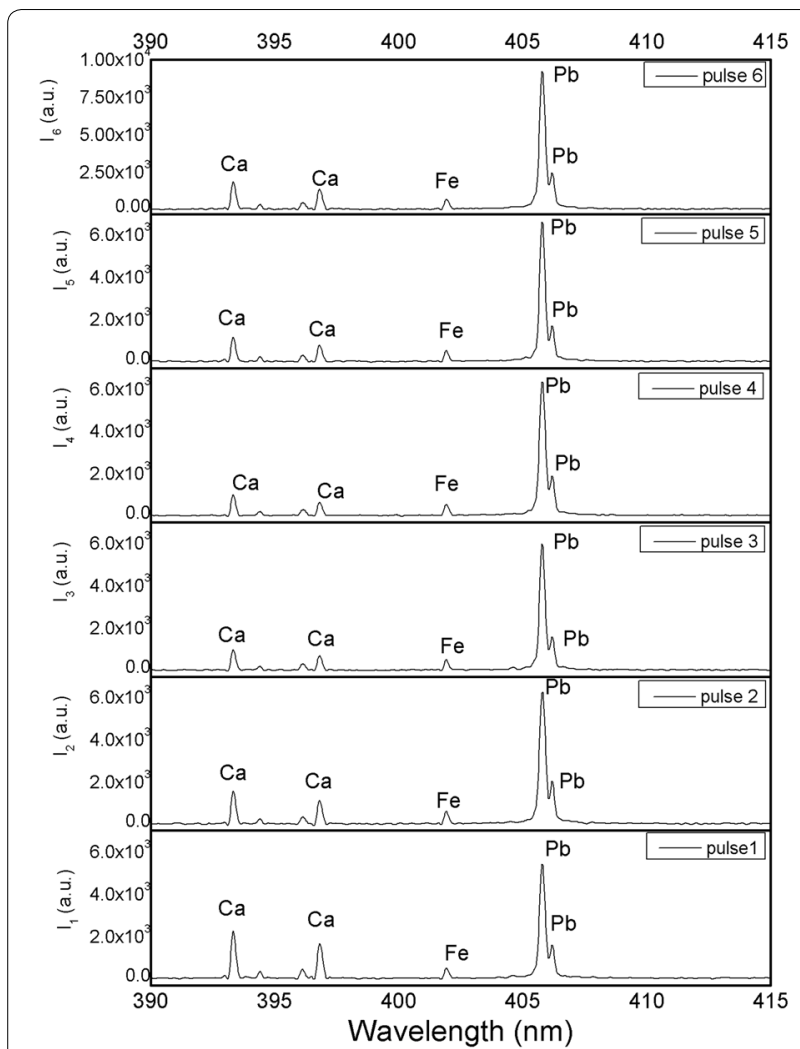

Fig. 7 LIBS spectra for the first six pulses, on the verso of sample S3

analysis carried on cross-sections, oxalates were found to be distributed within the upper paint layers.

\section{Red pigments}

Red, black, brown, yellow and green areas show the highest Fe lines, as well as the areas analyzed on the brown borders, all of which could be due to the use of iron oxide pigments [33]. Additionally, mercury is present at high levels on the red areas, the brown border, but also on area 45 , evidence of the pigment used for the red flower beneath the white stain. Also, the purple shades from the exterior lid (areas 36 and 43) show mercury lines. The most probable explanation would be the use of cinnabar or vermilion, HgS. Samples analyzed by FTIR sustain the use of a red ochre, characteristic absorptions for haematite being observed at $535 \mathrm{~cm}^{-1}$ and $467 \mathrm{~cm}^{-1}$ [40]. The presence of these red pigments does not, however, aid in time-framing the painted areas, as all three have been in use since antiquity, and throughout the 18-19th centuries $[33,35]$.

\section{Black and brown pigments}

$\mathrm{XRF}$ spectra revealed that manganese is present in black, brown and red areas (on the soundboard), possibly indicating the use of manganese-containing pigment, such manganese black $\left(\mathrm{MnO}_{2}\right)$ - mostly used in the nineteenth century, with few mentionings in the 16th-century oil paintings [41], or umber-used since antiquity.

Regarding the brown border which appears all over the interior of the lid, it appears that it is completely different from the shades of brown found on the painting which it frames. The borders are characterized by high levels of $\mathrm{Zn}$, but no other elements stand out, except maybe some minor lines of $\mathrm{Ba}$, and possibly $\mathrm{Cl}$. These elements are, most probably, associated with a nineteenth century restoration [5]. Similarly, the red paint observed in some places on top of the golden border also displays higher $\mathrm{Zn}$ levels, probably associated with the latest intervention on the instrument.

\section{Yellow pigments}

For yellow areas $(42,47)$, besides $\mathrm{Pb}$, higher chromium and iron lines were noticed. Considering the elements found, several possibilities exist for the yellow pigment: either lead-tin yellow (type $\mathrm{I}-\mathrm{Pb}_{2} \mathrm{SnO}_{4}$ or $\mathrm{II}-\mathrm{Pb}(\mathrm{Sn}, \mathrm{Si})$ $\mathrm{O}_{3}$, frequent in European paintings since the 14 century until the middle of the eighteenth century [35]), yellow ochre (used since antiquity) or chrome yellow- $\mathrm{PbCrO}_{4}$, barium/strontium yellow- $\mathrm{BaCrO}_{4} / \mathrm{SrCrO}_{4}$, zinc yellow $-\mathrm{K}_{2} \mathrm{O} \cdot 4 \quad \mathrm{ZnCrO}_{4} \cdot 3 \mathrm{H}_{2} \mathrm{O}$ (the last three first introduced in the early 1800 s $[33,35])$.

The use of natural ochres rich in kaolinite can be inferred based on the characteristic IR peaks observed at $3697,3652,3620 \mathrm{~cm}^{-1}$ (hydroxyl ion bands), $1030 \mathrm{~cm}^{-1}$ (Si-O-Si band), $1005 \mathrm{~cm}^{-1}$ (Si-O-Al band) and $912 \mathrm{~cm}^{-1}$ (Al-O-H band). Moreover, terrigenous materials have been identified by LIBS ( $\mathrm{Si}, \mathrm{Mn}, \mathrm{Ti}, \mathrm{Li}, \mathrm{Al}, \mathrm{Sm}$, $\mathrm{Eu})$ and by $\mathrm{XRF}(\mathrm{K}, \mathrm{Ti}, \mathrm{Al}, \mathrm{Rb}, \mathrm{Zr})$, which, correlated with the FTIR data, sustains the use of natural ochres [33, 41]. Iron oxides (peaks at 532 and $465 \mathrm{~cm}^{-1}$ ), as well as small amounts of quartz (characteristic IR peaks at 797 and $779 \mathrm{~cm}^{-1}$ ), were also highlighted, the presence of quartz being characteristic for French ochres [40].

\section{Green pigments}

Similarly to the yellow areas, chromium is present at higher levels in green areas, also. By analyzing the spectra collected from green areas on the small lid: 52 , 55 (interior), 39, 33, 31 (exterior), it can be seen that they differ through the presence, and, respectively, the absence of some major elements, as follows: area 33 has the most $\mathrm{Si}, \mathrm{K}, \mathrm{Ca}, \mathrm{Ba}$ and $\mathrm{Sr}$, which could correlate to a green earth pigment; areas 33, 52 and 55 contain $\mathrm{Mn}$ and $\mathrm{Cr}$ (possibly from a chromium oxide/viridian pigment), but also have the highest $\mathrm{Fe}$ and $\mathrm{Zn}$ content. Area 55 also has some As, which, in combination 


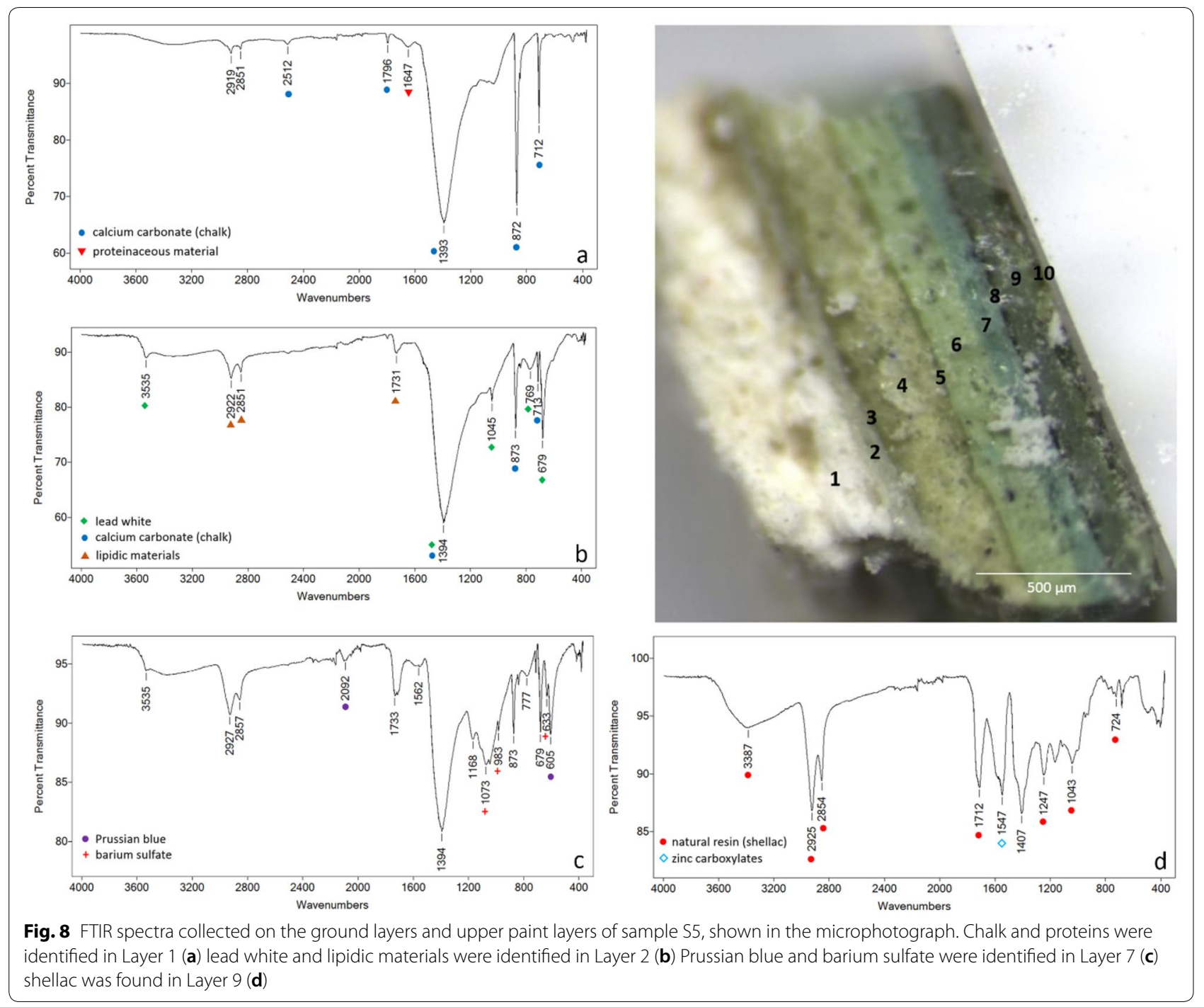

with $\mathrm{Cu}$ (the most intense) can infer a trace of emerald green, used since 1830 up until the early 1900s [33]. Green earth was known since antiquity, but the others are more modern pigments; Viridian $\left(\mathrm{Cr}_{2} \mathrm{O}_{3} \cdot 2 \mathrm{H}_{2} \mathrm{O}\right)$, was introduced in the second half of the 19th century, and the green chromium oxide had limited use as an artist's pigment, due to high manufacturing costs.

The weak absorptions (shoulder peaks) around $1558 \mathrm{~cm}^{-1}$ and $1455 \mathrm{~cm}^{-1}$ (COO- antisymmetric stretching) observed in the FTIR spectra registered on sample S5, may infer the presence of emerald green [42], a pigment introduced at the beginning of the nineteenth century [43].

An interesting aspect is the fact that the green borders, which appear to be made of the same paint as the green background, have larger quantities of zinc as compared to the other areas. This is an indication of the fact that a zinc-based pigment has been used for these areas, definitely pertaining to one of the most recent restoration interventions.

\section{Blue pigments}

High $\mathrm{Cu}$ levels were found on blue and purple shades from the keywell, implying the possibility of a copperbased paint having been used for the blue areas $(26,27)$, and a mixture of a copper pigment with a red organic dye which cannot be identified via XRF, for the purple shades (28). A known copper-based pigment specific was azurite, the bright blue hydrated copper carbonate $(\mathrm{Cu} 3(\mathrm{CO} 3) 2(\mathrm{OH}) 2)$, widely used since ancient times up until the end of the seventeenth century [34], mostly on tempera and oil paintings [34], after which its incidence started to decrease along with the discovery of Prussian blue at the beginning of the eighteenth century [23].

FTIR analysis identified Prussian blue within the interior layers (see Fig. 8c), by the diagnostic peak of the 
nitrile group at $2090 \mathrm{~cm}^{-1}(\mathrm{C} \equiv \mathrm{N})$, along the sharp peak around $605 \mathrm{~cm}^{-1}$ [43]. As indicated by the FTIR data, small amounts of Prussian blue seem to have been mixed with a copper-based pigment (most probably emerald green) to obtain the desired effect, a brilliant blue-green tone. This is not in disagreement with the XRF data, but would simply imply that the copper identified via XRF would actually come not from a blue, but from a green copper-based pigment, which would have been mixed with the Prussian blue.

\section{Gilding}

Both on the gilded area on the music desk and the golden lines on the outer case, gold has been identified as a major element, along with traces of silver and copper. The presence of copper, along with $\mathrm{Au}$ and $\mathrm{Ag}$, could indicate the use of a ternary $\mathrm{Au}-\mathrm{Ag}-\mathrm{Cu}$ alloy. The integration areas on the golden lines from the outer case showed more $\mathrm{Ca}$ and $\mathrm{Cu}$ than the rest of the golden areas, and also, less $\mathrm{Au}$ and $\mathrm{Pb}$. This might be correlated with the possible use of brass instead of gold foil, for a more recent intervention. These findings are in accordance with the results published in another scientific research conducted on a similar object, a study on an eighteenth century Pascal Taskin harpsichord located in Portugal, which found both silver and copper, in the gold foil used for gilding [9]. Gold foil had been applied over a resin layer (shellac, as was inferred by multispectral imaging and confirmed by FTIR). Moreover, optical microscopy images acquired for sample S1 (Fig. 9) showed the presence of not one, but two gold layers, in between which there is the shellac layer. The presence of two gold layers is sustained by the LIBS spectra acquired for this sample, in which, although Au has not been identified because it's signal is covered by that of $\mathrm{Ba}$, silver, which also comes from the gold foil, has been identified in the 1-4, and the 17-19 kinetic series. Fine particles of Prussian blue can also be seen under the second gold leaf on top of a copper-based paint layer, in accordance with the registered FTIR data.

\section{Organic materials}

As already discussed in the previous sections, FTIR analysis showed characteristic bands of proteinaceous binders within the first ground layer, most probably an animal glue. For the second ground layer, an oil-based system was used. FTIR analysis carried on superimposed paint layers revealed the existence of an oil/protein binder. Characteristic features for aged oil systems were observed in most of the registered spectra, various metal carboxylates being identified (lead, zinc and copper soaps) [37],

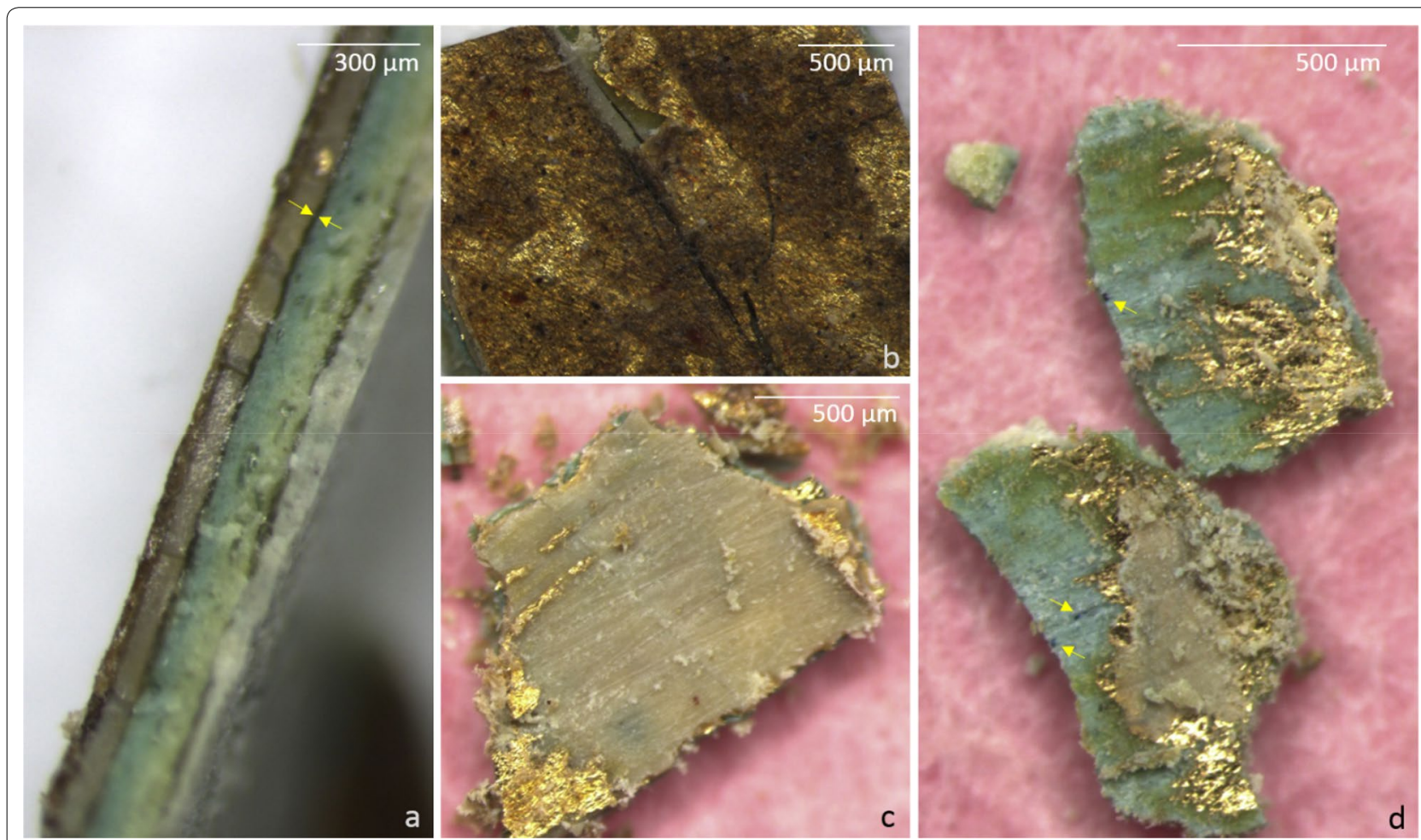

Fig. 9 Cross-section of sample S1 (a) and microscopic details highlighting the existence of a second gold leaf under the shellac resin layer: top gold leaf (b) the intermediate layer of resin (c) second sheet of gold (d) 
correlated with the high amount of C detected by LIBS in the analyzed samples. Clear indicators for proteinaceous compounds were also observed mainly via the Amide I band centered at $1648 \mathrm{~cm}^{-1}$. Calcium oxalates were also observed both at the surface and interior layers, partially related to the atmospheric exposure of old varnish. Taken into account the rich history of the object, most probably different binding media have been used within the various layers, the applied painting technique being closely related to the subsequent interventions that the harpsichord went through $[5,9]$.

The presence of a size layer (isolation layer) was also highlighted in most of the analyzed samples. FTIR analysis carried on cross-sections (Fig. 8d) indicate that an intermediate sizing layer based on shellac was used: characteristic absorptions centered around 3387, 2925, $2854,1712,1247,1040,724 \mathrm{~cm}^{-1}$ [43]. The use of such size layers was documented in various historical recipes of the nineteenth century [22], shellac being used (alone or mixed with ammonia) to render the layer more waterresistant and obtain a smooth finish. Other sources [22] mention the use of shellac also as a binder in colored ground layers, although its rather dark tone, when applied without any treatment, limited its use.

\section{Conclusions}

The pictorial decorations of a Pascal Taskin harpsichord, created in 1772 were analyzed in this study by an array of non-invasive and micro-invasive techniques. Obtained results provide new insights and a greater understanding of the pictorial/decorative techniques used in Taskin's atelier.

Multispectral imaging revealed a series of details regarding the pictorial technique, past interventions, as well as various degradations that were affecting the painting layers. Results of the combined analytic approach offered an in-depth view of the exiting color palette, various pigments being identified: lead white, zinc white, vermilion, iron red, yellow ochre, manganese black, green earth, azurite, Prussian blue, chromium oxides. Emerald green, zinc yellow and lead tin yellow may also have been used. FTIR analysis carried out on samples highlighted the existence of a double ground: first layer based on chalk and animal glue covered by a second layer based on lead white bound in an oil binder. An intermediate sizing layer (isolation layer) based on shellac was found in most of the analyzed samples, on top of a sequence of pictorial layers in shades of green.

A general overview of the existing interventions could be highlighted with multispectral imaging by analyzing the variations in the absorption level of the UV radiation. Various fillings, consolidation, and chromatic reintegration areas were documented. The presence of barium sulfate, zinc white as well as emerald green in the upper paint layers, as indicated by the results obtained on crosssections, can be correlated with later interventions, all of these materials being introduced at the beginning of the nineteenth century. The complex stratigraphy, with up to ten layers in some of the analyzed samples, highlights specific interventions, either at the level of the paint layer-as retouches and chromatic reintegrations, either at the level of the gold foil. The application of a second gold foil on top of the original one in between a sizing layer based on shellac resin was most probably due to the eroded original gilding. As indicated by the orange fluorescence (given by shellac) on small areas located on the keywell, these interventions are narrow, probably done at that moment only in the most degraded areas. Interventions could be highlighted on the exterior frame of the painted panels, as well as on the legs, these areas showing a lower number of layers.

The overall results led to the idea that the instrument had undergone several interventions along the time. Most probably, the soundboard contains pieces of original seventeenth century Ruckers or Flemish instrument(s). Initially, the harpsichord had probably a pale green exterior, probably resembling the 1769 Taskin harpsichord preserved in the St Cecilia's Hall musical instruments collection, in Edinburgh, UK. Over time, due to degradations as well as to changes in style and aesthetic taste, the harpsichord suffered a series of interventions. Most probably, in the late eighteenth century or the beginning of the nineteenth century, the sides of the case and the inside lid were painted, probably by more than one person. Another time frame is related to the exterior lid decorations, probably pertaining to the end of nineteenth century or the beginning of the twentieth century.

The findings are of great interest to conservators, restorers and art historians alike, by offering valuable insights necessary for the pictorial layers' restoration process of this unique artifact. Not least, obtained results increase information regarding the complex history of harpsichord's decoration. The instrument is a witness of the past, telling the tale of centuries, of changing styles and preferences around this type of decorative musical instruments.

\section{Supplementary information}

Supplementary information accompanies this paper at https://doi. org/10.1186/s40494-020-00401-3.

Additional file 1. Detailed XRF analysis areas and FTIR spectra of S2-S3.

\section{Abbreviations}

MSI: Multispectral imaging; XRF: X-ray fluorescence; LIBS: Laser-induced breakdown spectroscopy; FTIR: Fourier transform infrared spectroscopy; OM: Optical microscopy; CCD: Charge-coupled detector; UV: Ultraviolet; NIR: Near-infrared; VIS: Visible; Nd: Neodymium-doped; YAG: Yttrium aluminum garnet. 


\section{Acknowledgements}

The authors gratefully acknowledge The Peleș National Museum for allowing in situ access to the harpsichord. We also gratefully acknowledge ANTIQVA Association for the information about the history of the artifact and the photographic details provided. Authors would like to thank Mrs. Pascale Vandervellen, from the Musical Instruments Museum, Brussels, Belgium for sharing with us her significant expertise in the field of harpsichords, for her patience and perfectionism, which helped significantly improve the quality of the paper.

\section{Authors' contributions}

IMC and LG designed the work; collected, processed and interpreted OM, XRF, and FTIR data; and led the writing of the manuscript; LR performed MSI investigations and helped with the interpretation of the results; MD performed LIBS analyses and processed the data; RR coordinated the data collection and supervised the preparation of the manuscript. All authors read and approved the final manuscript.

\section{Funding}

This research was funded by the Romanian Ministry of Research and Innovation CCCDI-UEFISCDI under Programme 1. Development of the National R-D System, 1.2. Institutional Performance-PFE-CDI nr.19/2018, ProINSTITUTIO, and under project IMPLEMENT, grant number PN-III-P1-1.2-PCCDI-2017-0878.

\section{Availability of data and materials}

The datasets used and/or analyzed during the current study are available from the corresponding author on reasonable request.

\section{Competing interests}

The authors declare that they have no competing interests.

Received: 27 February 2020 Accepted: 7 June 2020

Published online: 12 June 2020

\section{References}

1. Brien G. Ruckers: a harpsichord and virginal building tradition. Cambridge: Cambridge University Press; 1990.

2. Kottick EL. The Harpsichord Owner's guide: a manual for buyers and owners. Revised. Chapel Hill: University of North Carolina Press; 1992.

3. Kottick EL. A history of the harpsichord. 1st ed. Bloomington: Indiana University Press; 2003.

4. Restelli A. Il cembalaro del re alla sbarra. Pascal Taskin e i falsi Ruckers. Rivista Italiana Di Musicologia. 2015;50:61-77. www.jstor.org/stable/44653 043. Accessed 21 May 2020

5. Vandervellen P. The golden age of flemish harpsichord making: a study of the MIM's Ruckers instruments. Brussels: Musical Instruments Museum; 2017.

6. Bachelin L. Castel Pelesch. Le Chateau Royal de Sinaia. FIRMIN DIDOT \& Cie: Paris. 1893, cited by Mobile Cultural Objects Listed in the National Cultural Heritage. http://clasate.cimec.ro/.

7. Germann S. Harpsichord decoration: a conspectus. In: Scott H, editor. The historical harpsichord, vol. IV. Hillsdale: Pendragon Press; 2002.

8. Haugsand K. Personal communication. 2017. https://www.facebook. com/perspektiva2.0/videos/844282029083523/?v=844282029083523. Accessed 21 May 2020.

9. Estompa R, Frade JC, Pessanha S, Madeira TI, Cardoso A, Piorro L, Dias L, Mirão J, Candeias A, Carvalho ML. Multianalytical approach for the authenticity of an eighteenth century Pascal Taskin harpsichord. J Anal At Spectrom. 2012;27:626-43. https://doi.org/10.1039/c2ja10226a.

10. Mobile Cultural Objects Listed in the National Cultural Heritage. http:// clasate.cimec.ro/detaliu.asp?tit=Instrument-muzical-Taskin-Pascal-Clave cin\&k=B449126E92254FB8B57598FF1439A86A.

11. Germann S. Monsieur doublet and his confrères: the harpsichord decorators of Paris. Early Music. 1980;8:435-53. https://doi.org/10.1093/early j/8.4.435.

12. Germann S. Monsieur doublet and his confrèrs: the harpsichord decorators of Pariss 2. Early Music. 1981;9:192-212. https://doi.org/10.1093/early j/9.2.192.

13. Taylor RS, Hubbard F. Three centuries of harpsichord making. Notes. 1966;23:48-50. https://doi.org/10.2307/895143.
14. Echard JP, Laloue C, Chochod I, Pipitone D. Characterization and conservation of the decorative paint on seventeenth-century French and Flemish harpsichord soundboards. Stud Conserv. 2012;57:S103-13. https ://doi.org/10.1179/2047058412Y.0000000018.

15. Hebbert B. Flemish harpsichords and virginals. Heilbrunn timeline of art history. New York: The Metropolitan Museum of Art; 2016

16. Pelagotti A, Mastio AD, De Rosa A, Piva A. Multispectral imaging of paintings: a way to material identification. IEEE Signal Process Mag. 2008;25:27-36. https://doi.org/10.1109/MSP.2008.923095.

17. Grifoni E, Briganti L, Marras L, Orsini S, Colombini MP, Legnaioli S, Lezzerini M, Lorenzetti G, Pagnotta S, Palleschi V. The chemical-physical knowledge before the restoration: the case of 'The Plague in Lucca', a masterpiece of Lorenzo Viani (1882-1936). Herit Sci. 2015;3:26. https://doi.org/10.1186/ s40494-015-0055-0.

18. Delaney JK, Walmsley E, Berrie BH, Fletcher CF. Multispectral imaging of paintings in the infrared to detect and map blue pigments., Scientific examination of art modern techniques in conservation and analysisWashington: The National Academies Press; 2005. https://doi. org/10.17226/11413.

19. Daffara C, Pampaloni E, Pezzati L, Barucci M, Fontana R. Scanning multispectral IR reflectography SMIRR: an advanced tool for art diagnostics. Acc Chem Res. 2010;43:847-86. https://doi.org/10.1021/ar900268t.

20. Carden ML. Use of ultraviolet light as an aid to pigment identification. APT Bull. 1991. https://doi.org/10.2307/1504337.

21. Pelagotti A, Pezzati L, Bevilacqua N, Vascotto V, Reillon V, Daffara C. A study of UV fluorescence emission of painting materials. In: 8th International Conference on "Non-destructive investigations and microanalysis for the diagnostics and conservation of the cultural and environmental heritage. Lecce (Italy), 15-19 May 2005, 2005.

22. Stols-Witlox M. A perfect ground: preparatory layers for oil paintings, 1550-1900. London: Archetype Publications; 2017.

23. Roy A. artists' pigments a handbook of their history and characteristics, vol. 2. Washington: National Gallery of Art; 1993.

24. Gunasekaran S, Anbalagan G, Pandi S. Raman and infrared spectra of carbonates of calcite structure. J Raman Spectrosc. 2006;37:892-9. https //doi.org/10.1002/jrs.1518.

25. Antunes V, Candeias A, Mirão J, Carvalho ML, Barrocas Dias C, Manhita A, Cardoso A, Francisco MJ, Lauw A, Manso M. Analytical characterization of the palette and painting techniques of Jorge Afonso, the great 16th century Master of Lisbon painting workshop. Spectrochim Acta A. 2018;193:264-75. https://doi.org/10.1016/j.saa.2017.12.027.

26. Zumbühl S, Scherrer NC, Eggenberger U. Derivatization technique to increase the spectral selectivity of two-dimensional fourier transform infrared focal plane array imaging: analysis of binder composition in aged oil and tempera paint. Appl Spectrosc. 2014;68:458-65. https://doi. org/10.1366/13-07280.

27. Miliani C, Rosi F, Daveri A, Brunetti BG. Reflection infrared spectroscopy for the non-invasive in situ study of artists' pigments. Appl Phys A. 2012;106:295-307. https://doi.org/10.1007/s00339-011-6708-2.

28. Gonzalez V, Calligaro T, Wallez G, Eveno M, Toussaint K, Menu M. Composition and microstructure of the lead white pigment in Masters paintings using HR Synchrotron XRD. Microchem J. 2016;125:43-9. https://doi. org/10.1016/j.microc.2015.11.005.

29. Balakhnina IA, Brandt NN, Chikishev AY, Grenberg YI, Grigorieva IA, Kadikova IF, Pisareva SA. Fourier transform infrared (FT-IR) microspectroscopy of 20th century russian oil paintings: problem of dating. Appl Spectrosc. 2016;70:1150-6. https://doi.org/10.1177/0003702816652330.

30. Boucher $\amalg$, Koeber K, Tille D, Demmer H, Köttelwesch H, Schleitzer-Rust E. Coordination Compounds of Manganese. In: Demmer H, Köttelwesch H, Schleitzer-Rust E, Tille D, eds. Gmelin Handbook of inorganic chemistry. Berlin: Springer. https://doi.org/10.1007/978-3-662-08178-5_1.

31. Bernardini S, Bellatreccia F, Casanova Municchia A, Della Ventura G, Sodo A. Raman spectra of natural manganese oxides. J Raman Spectrosc. 2019:50:873-88. https://doi.org/10.1002/jrs.5583.

32. Julien CM, Massot M, Poinsignon C. Lattice vibrations of manganese oxides: part I. Periodic structures. Spectrochim Acta A. 2018;60:689-700. https://doi.org/10.1016/S1386-1425(03)00279-8.

33. Eastaugh N, Walsh V, Chaplin T, Siddall R, editors. Pigment compendium: a dictionary and optical microscopy of historical pigments. New York: Routledge; 2013 
34. Istudor I. Notions of painting chemistry (in Romanian). Bucharest: ACS Publishing; 2011.

35. Feller RL, editor. Artist's pigments: a handbook of their history and characteristics, vol. 1. London: Archetype Publications; 2012.

36. Marino B, Boon J, Hendriks E, Horréard F, Hillion F. Imaging TOFSIMS and NanoSIMS studies of Barite-Celestite particles in grounds from paintings by Van Gogh. e-PS. 2006;3:41-50.

37. Otero V, Sanches D, Montagner C, Vilarigues M, Carlyle L, Lopes JA, Melo MJ. Characterisation of metal carboxylates by Raman and infrared spectroscopy in works of art. J Raman Spectrosc. 2014;45:1197-206. https:// doi.org/10.1002/jrs.4520.

38. Romano C, Lam T, Newsome GA, Taillon JA, Little N, Sun Tsang J. Characterization of zinc carboxylates in an oil paint test panel. Stud Conserv. 2020;65:14-27. https://doi.org/10.1080/00393630.2019.1666467.

39. Nevin A, Melia JL, Osticioli I, Gautier G, Colombini MP. The identification of copper oxalates in a 16th century Cypriot exterior wall painting using micro FTIR, micro Raman spectroscopy and gas chromatography-mass spectrometry. J. Cult. Herit. 2008;9:154-61. https://doi.org/10.1016/j.culhe r.2007.10.002
40. Genestar C, Pons C. Earth pigments in painting: characterisation and differentiation by means of FTIR spectroscopy and SEM-EDS microanalysis. Anal Bioanal Chem. 2005;382:269-74. https://doi.org/10.1007/s0021 6-005-3085-8.

41. Popelka-Filcoff RS, Robertson JD, Glascock MD, Descantes C. Trace element characterization of ochre from geological sources. J Radioanal Nucl Chem. 2007:272:17-27. https://doi.org/10.1007/s10967-006-6836-x.

42. FitzHugh EW. Artists' pigments: a handbook of their history and characteristics, vol. 3. London: Archtype Publications; 1997.

43. Derrick MR, Stulik D, Landry JM. Infrared spectroscopy in conservation science. Los Angeles: The Getty Conservation Institute; 2015.

\section{Publisher's Note}

Springer Nature remains neutral with regard to jurisdictional claims in published maps and institutional affiliations.

\section{Submit your manuscript to a SpringerOpen ${ }^{\circ}$ journal and benefit from:}

- Convenient online submission

- Rigorous peer review

- Open access: articles freely available online

- High visibility within the field

- Retaining the copyright to your article

Submit your next manuscript at $\boldsymbol{\nabla}$ springeropen.com 